University of Nebraska - Lincoln

DigitalCommons@University of Nebraska - Lincoln

Roman L. Hruska U.S. Meat Animal Research

U.S. Department of Agriculture: Agricultural Center

Research Service, Lincoln, Nebraska

$1-1-2021$

\title{
Use of bedding materials in beef bedded manure packs in hot and cool ambient temperatures: Effects on ammonia, hydrogen sulfide, and greenhouse gas emissions
}

\author{
Jeff P. Jaderborg \\ University of Minnesota Twin Cities \\ Mindy J. Spiehs \\ USDA-ARS, mindy.spiehs@ars.usda.gov \\ Bryan L. Woodbury \\ USDA ARS Roman L. Hruska U.S. Meat Animal Research Center \\ Alfredo DiCostanzo \\ University of Minnesota Twin Cities \\ David B. Parker \\ USDA ARS Conservation and Production Research Laboratory
}

\footnotetext{
Follow this and additional works at: https://digitalcommons.unl.edu/hruskareports

Part of the Beef Science Commons, and the Meat Science Commons
}

\footnotetext{
Jaderborg, Jeff P.; Spiehs, Mindy J.; Woodbury, Bryan L.; DiCostanzo, Alfredo; and Parker, David B., "Use of bedding materials in beef bedded manure packs in hot and cool ambient temperatures: Effects on ammonia, hydrogen sulfide, and greenhouse gas emissions" (2021). Roman L. Hruska U.S. Meat Animal Research Center. 562.

https://digitalcommons.unl.edu/hruskareports/562
}

This Article is brought to you for free and open access by the U.S. Department of Agriculture: Agricultural Research Service, Lincoln, Nebraska at DigitalCommons@University of Nebraska - Lincoln. It has been accepted for inclusion in Roman L. Hruska U.S. Meat Animal Research Center by an authorized administrator of DigitalCommons@University of Nebraska - Lincoln. 


\title{
Use of Bedding Materials in BeEF Bedded Manure PACKS IN HOT AND COOL AMBIENT TEMPERATURES: EFFECTS ON AMMONIA, HYDROGEN SULFIDE, AND GREENHOUSE GAS EMISSIONS
}

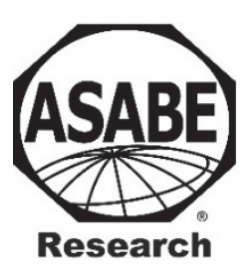

\author{
Jeff P. Jaderborg', Mindy J. Spiehs ${ }^{2, *}$, Bryan L. Woodbury², \\ Alfredo DiCostanzo ${ }^{1}$, David B. Parker ${ }^{3}$ \\ ${ }^{1}$ Department of Animal Science, University of Minnesota, St. Paul, Minnesota, USA. \\ ${ }^{2}$ USDA-ARS U.S. Meat Animal Research Center, Clay Center, Nebraska, USA. \\ ${ }^{3}$ USDA-ARS Conservation and Production Research Laboratory, Bushland, Texas, USA. \\ *Correspondence: mindy.spiehs@ars.usda.gov.
}

\section{HighLIGHTS}

- Lab-scale beef manure bedded packs were constructed to evaluate the temperature effect on gaseous emissions.

- Temperature had a tendency to increase ammonia, hydrogen sulfide, and greenhouse gases in the headspace above bedded packs over time.

\begin{abstract}
Throughout the Upper Midwest, producers have observed increased land and fertilizer prices, resulting in increased popularity of confinement feeding facilities such as mono-slope and hoop barns with bedded packs. Environmental and public pressure has been placed on the agriculture community to reduce ammonia $\left(\mathrm{NH}_{3}\right)$, hydrogen sulfide $\left(\mathrm{H}_{2} \mathrm{~S}\right)$, and greenhouse gas (GHG) emissions from concentrated animal feeding operations (CAFOs). This study was conducted to determine the effects of bedding material (corn stover (CS), bean stover (BS), wheat straw (WS), or pine wood chips (PC)) and ambient temperature $\left(15^{\circ} \mathrm{C}(\mathrm{COOL})\right.$ or $\left.30^{\circ} \mathrm{C}(\mathrm{HOT})\right)$ on $\mathrm{NH}_{3}, \mathrm{CH}_{4}, \mathrm{CO}_{2}, \mathrm{~N}_{2} \mathrm{O}$, and $\mathrm{H}_{2} \mathrm{~S}$ flux in air samples collected in the headspace above lab-scale bedded packs. All bedded packs were housed at $18^{\circ} \mathrm{C}$ for an initial three weeks before being placed in their respective environmental chambers at $15^{\circ} \mathrm{C}$ or $30^{\circ} \mathrm{C}$ for the remainder of the 6-week study period. Significant two-way interactions of bedding material by temperature for $\mathrm{NH}_{3}$ flux were observed $(p=0.0094)$. Ammonia flux was greater at higher temperature, while CS bedding had the lowest $\mathrm{NH}_{3}$ emissions compared to the other bedding materials. A significant two-way interaction of bedding material by temperature for $\mathrm{H}_{2} \mathrm{~S}$ flux was observed ( $p<0.0001$ ), with significantly greater $\mathrm{H}_{2} \mathrm{~S}$ produced in the headspace of COOL-BS packs compared to all other treatments. Additionally, a significant $(p=0.0357)$ two-way interaction of temperature by age of the bedded pack was observed for $\mathrm{H}_{2} \mathrm{~S}$ flux. Hydrogen sulfide flux appeared to be influenced by low bedded pack $\mathrm{pH}$ to a greater extent than by increase in temperature. Greenhouse gas emissions tended to be higher from bedded packs in HOT treatments. A significant $(p=0.0422)$ interaction among bedding material, temperature, and age of the bedded pack was observed for $\mathrm{CH}_{4}$. Significantly greater $\mathrm{CH}_{4}$ flux was observed in the headspace above HOT-BS and HOT-CS at week 6 compared to all other treatments. A significant two-way interaction of bedding material by temperature was observed for $\mathrm{CO}_{2}$ flux $(p=0.0189)$. The largest $\mathrm{CO}_{2}$ levels were observed above WS bedding material regardless of temperature. Nitrous oxide flux decreased over the 6-week study for all bedded packs, while WS and PC bedded packs produced the greatest $\mathrm{N}_{2} \mathrm{O}$ flux. The results indicate that feedlot operators maintaining bedded pack facilities will have the greatest reduction in $\mathrm{NH}_{3}$ emissions when using CS bedding, regardless of ambient temperature. To reduce $\mathrm{CH}_{4}$ emissions, producers should avoid allowing $B S$ and CS bedded packs that are maintained for longer than six weeks in $\mathrm{HOT}\left(30^{\circ} \mathrm{C}\right)$ temperatures; frequent cleaning during summer months is recommended. Based on the $\mathrm{CO}_{2}$ equivalents of $\mathrm{CH}_{4}$ and $\mathrm{N}_{2} \mathrm{O}$, producers should consider $\mathrm{PC}$ as an option to reduce GHG emissions.
\end{abstract}

Keywords. Ammonia, Bedding age, Bedding type, Beef, Carbon dioxide, Greenhouse gas, Hydrogen sulfide, Methane, Nitrous oxide, Temperature.

Submitted for review on 1 September 2020 as manuscript number PAFS 14291; approved for publication as a Research Article by the Plant, Animal, \& Facility Systems Community of ASABE on 16 April 2021.

Mention of company or trade names is for description only and does not imply endorsement by the USDA. The USDA is an equal opportunity provider and employer.

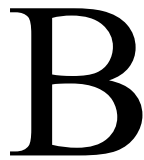
eef feedlot producers in the Upper Great Plains and Midwest regions of the U.S. are building beef confinement feeding facilities to address the environmental and management issues associated with livestock production. Slatted-floor facilities require no bedding, but mono-slope and hoop facilities are typically 
bedded for animal comfort. A variety of bedding materials are used, with the most common being crop residues such as corn stover (CS), bean stover (BS), and wheat straw (WS) (Doran et al., 2010). Livestock manure is recognized as a source of ammonia $\left(\mathrm{NH}_{3}\right)$ and greenhouse gas $(\mathrm{GHG})$ emissions from animal agriculture (Miller and Varel, 2001; Chadwick et al., 2011), and the bedding-manure mixture in confinement beef facilities is a potential source of gas emissions. To reduce $\mathrm{NH}_{3}$ and $\mathrm{GHG}$ emissions from concentrated animal feed operations (CAFOs), feedlot operators evaluate many management decisions that impact gases, including feed, facility cleaning, animal type and age, and type of bedding material. Bedding material type has been reported to influence gaseous emissions (Misselbrook and Powell, 2005; Garlipp et al., 2011; Spiehs et al., 2012, 2014b, 2016; Ayadi et al., 2015).

The GHG contribution from ruminants has been heavily focused on methane $\left(\mathrm{CH}_{4}\right)$ production from enteric fermentation (Johnson and Johnson, 1995; Kebreab et al., 2008), although microbial decomposition of manure produced at CAFOs also results in $\mathrm{NH}_{3}, \mathrm{CH}_{4}$, carbon dioxide $\left(\mathrm{CO}_{2}\right)$, and nitrous oxide $\left(\mathrm{N}_{2} \mathrm{O}\right)$ production (Mackie et al., 1998). Undigested dietary nitrogen excreted in urine and feces contributes to $\mathrm{NH}_{3}$ emissions (Archibeque et al., 2007). Ammonia volatilization increases with increasing temperature, reduction in dry matter content, $\mathrm{pH}$, air movement, and other factors (Meisinger and Jokela, 2000). Potential negative respiratory health effects from $\mathrm{NH}_{3}$ volatilization are a concern for confinement workers (Mitloehner and Calvo, 2008) and animals. Ammonia exposure of 300 ppm is considered immediately dangerous to life or health (IDLH) for humans by the National Institute for Occupational Safety and Health (NIOSH; Ludwig et al., 1994). Ayadi et al. (2015) reported that $\mathrm{NH}_{3}, \mathrm{CH}_{4}, \mathrm{CO}_{2}$, and $\mathrm{N}_{2} \mathrm{O}$ concentrations in the headspace above lab-scale bedded packs were higher at $40^{\circ} \mathrm{C}$ compared to $10^{\circ} \mathrm{C}$. Bedded packs using CS compared to BS resulted in greater $\mathrm{NH}_{3}$ concentrations when ambient temperatures were $40^{\circ} \mathrm{C}$. Previously, Spiehs et al. (2016) reported that bedded packs containing greater than $20 \%$ pine chips (PC) in a CS mixture reduced $\mathrm{NH}_{3}$ by up to $14 \%$. Regardless of the percentages of $\mathrm{PC}$ and $\mathrm{CS}$ in the bedding mixture, $\mathrm{GHG}\left(\mathrm{CH}_{4}, \mathrm{CO}_{2}\right.$, and $\left.\mathrm{N}_{2} \mathrm{O}\right)$ concentrations throughout the 6-week bedded pack study did not differ $(p>0.61)$.

In addition to contributing to odor, hydrogen sulfide $\left(\mathrm{H}_{2} \mathrm{~S}\right)$ emissions from livestock facilities are a safety concern because $\mathrm{H}_{2} \mathrm{~S}$ exposure can cause human and livestock fatalities (Hooser et al., 2000). Hydrogen sulfide exposure of $100 \mathrm{ppm}$ is considered IDLH for humans by NIOSH (Ludwig et al., 1994). Hydrogen sulfide emissions are associated with liquid manure (Parker et al., 2010). Bedded packs lack the large volumes of liquid manure found in slatted-floor deep-pit facilities or manure lagoons and lack of agitation of the liquid that causes air bubbles containing $\mathrm{H}_{2} \mathrm{~S}$ to burst, thereby releasing $\mathrm{H}_{2} \mathrm{~S}$ emissions ( $\mathrm{Ni}$ et al., 2009). For these reasons, $\mathrm{H}_{2} \mathrm{~S}$ emissions are relatively low in bedded pack facilities. To date, no $\mathrm{H}_{2} \mathrm{~S}$ emission data have been reported for beef mono-slope barns with deep-pits. In bedded pack environments, $\mathrm{H}_{2} \mathrm{~S}$ flux is produced as a result of sulfate-reducing obligate anaerobic bacteria (Zang et al., 2017). Obligate anaerobic bacterial degradation of sulfur-containing proteins and organic matter (OM) excreted by livestock consuming diets high in corn distillers grains with solubles (DGS) or sulfur amino acids (cysteine and methionine) has been reported as the main contributor to $\mathrm{H}_{2} \mathrm{~S}$ emissions ( $\mathrm{Li}$ et al., 2011; Mackie et al., 1998).

The objective of this study was to determine the effects of bedding material and environmental ambient temperature on flux of $\mathrm{NH}_{3}, \mathrm{CH}_{4}, \mathrm{CO}_{2}, \mathrm{~N}_{2} \mathrm{O}$, and $\mathrm{H}_{2} \mathrm{~S}$ from bedded packs.

\section{Materials ANd Methods \\ BEDDING Material}

Corn stover, bean stover, wheat straw, and pine wood chips were used in this lab-scale bedded pack study. Corn stover, BS, and WS were sourced locally and processed in an Earthquake chipper/shredder (Ardisam, Inc., Cumberland, Wisc.) before being sifted through a $6.35 \mathrm{~mm}$ screen to remove fines as described by Spiehs et al. (2013). Kiln-dried pine wood chips were purchased commercially (Ozark Shavings Co., Licking, Mo.). Composition of the bedding materials was previously reported by Spiehs et al. (2013).

\section{Lab-SCALe Bedded PaCKS}

Lab-scale bedded packs were built using $0.43 \mathrm{~m}$ high and $0.38 \mathrm{~m}$ diameter plastic containers with no lids (fig. 1), as previously described by Spiehs (2018). To allow air movement, each container had six $10 \mathrm{~mm}$ holes spaced equally around its circumference, approximately $50 \mathrm{~mm}$ from the top of the container (Spiehs, 2018). During gas flux sample collection, $5 \mathrm{~L} \mathrm{~min}^{-1}$ of positive pressure was supplied with only $1 \mathrm{~L} \mathrm{~min}{ }^{-1}$ collected for sampling.

Initially, $400 \mathrm{~g}$ of bedding treatment material was used for the base bedded pack. Three times per week, on Monday, Tuesday, and Thursday for the Tuesday sample collection group (environmental chambers A and B) and on Tuesday, Wednesday, and Friday for the Wednesday sample collection group (environmental chambers $\mathrm{C}$ and $\mathrm{D}$ ), $300 \mathrm{~g}$ of cattle feces and $300 \mathrm{~mL}$ of cattle urine (adjusted to $\mathrm{pH} 7.4$ ) were added to the bedded pack surfaces (fig. 2). Feces and urine were obtained and composited separately from feedlot cattle consuming a typical late finisher diet containing a maximum

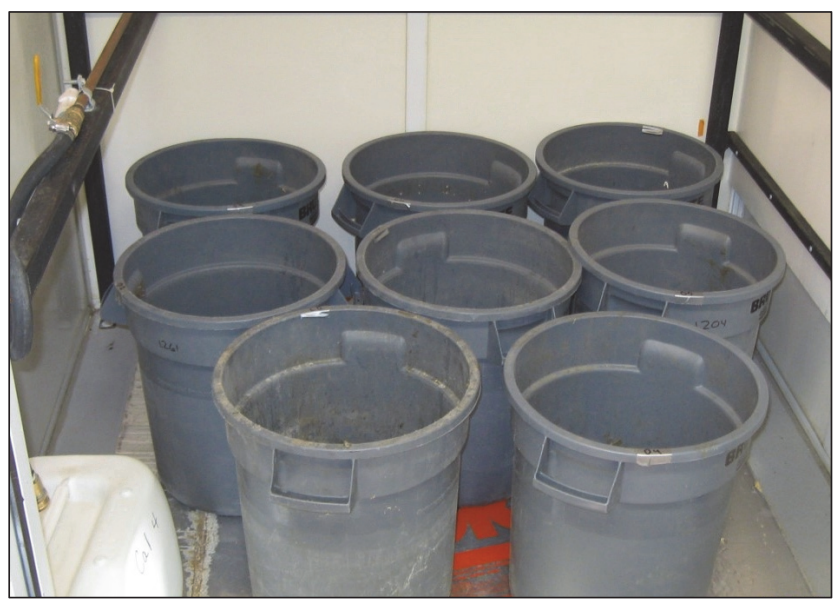

Figure 1. Lab-scale bedded packs containing corn stover, bean stover, wheat straw, or pine wood chips and stored at cool $\left(15^{\circ} \mathrm{C}\right)$ or hot $\left(30^{\circ} \mathrm{C}\right)$ temperatures in environmental chambers. 


\begin{tabular}{|c|c|c|c|}
\hline $\begin{array}{l}\text { Environmental } \\
\text { Chamber "A" }\end{array}$ & $\begin{array}{l}\text { Environmental } \\
\text { Chamber "B" }\end{array}$ & $\begin{array}{l}\text { Environmental } \\
\text { Chamber "C" }\end{array}$ & $\begin{array}{l}\text { Environmental } \\
\text { Chamber "D" }\end{array}$ \\
\hline $\mathrm{COOL} 15^{\circ} \mathrm{C}$ & HOT $30^{\circ} \mathrm{C}$ & $\mathrm{COOL} 15^{\circ} \mathrm{C}$ & HOT $30^{\circ} \mathrm{C}$ \\
\hline $\begin{array}{c}\text { Feces, urine and } \\
\text { bedding material } \\
\text { added Monday, } \\
\text { Tuesday, and } \\
\text { Thursday }\end{array}$ & $\begin{array}{c}\text { Feces, urine and } \\
\text { bedding material } \\
\text { added Monday, } \\
\text { Tuesday, and } \\
\text { Thursday }\end{array}$ & $\begin{array}{c}\text { Feces, urine and } \\
\text { bedding material } \\
\text { added Tuesday, } \\
\text { Thursday, and } \\
\text { Friday }\end{array}$ & $\begin{array}{c}\text { Feces, urine and } \\
\text { bedding material } \\
\text { added Tuesday, } \\
\text { Thursday, and } \\
\text { Friday }\end{array}$ \\
\hline $\begin{array}{c}\text { Samples collected } \\
\text { Tuesday }\end{array}$ & $\begin{array}{c}\text { Samples collected } \\
\text { Tuesday }\end{array}$ & $\begin{array}{c}\text { Samples collected } \\
\text { Wednesday }\end{array}$ & $\begin{array}{c}\text { Samples collected } \\
\text { Wednesday }\end{array}$ \\
\hline
\end{tabular}

Figure 2. Lab-scale bedded pack layout, material additions, and sample collection times in environmental chambers $\mathrm{A}, \mathrm{B}, \mathrm{C}$, and $\mathrm{D}$ at cool $\left(15^{\circ} \mathrm{C}\right)$ or hot $\left(30^{\circ} \mathrm{C}\right)$ temperatures. Bedding material was corn stover (CS), bean stover (BS), wheat straw (WS), or pine wood chips (PC).

of $30 \%$ wet corn distillers grains with solubles (WDGS). Bedding ( $200 \mathrm{~g})$ was added once weekly on the day of sample collection after gas sample collection was completed. Following the addition of feces, urine, and bedding material, the bedded pack was mixed for $30 \mathrm{~s}$ using a plastic-covered $5.08 \mathrm{~cm}$ steel rod to imitate live animal hoof activity.

Air samples were collected from the bedded packs once weekly on day 28,35 , and 42 for $\mathrm{NH}_{3}, \mathrm{CH}_{4}, \mathrm{CO}_{2}, \mathrm{~N}_{2} \mathrm{O}$, and $\mathrm{H}_{2} \mathrm{~S}$ measurement before the addition of feces, urine, and bedding material. Pack temperature, pack height, and $\mathrm{pH}$ were also collected from the bedded packs once weekly on day 28 , 35 , and 42 before the addition of feces, urine, and bedding material. Each 6-week period used four environmental chambers, controlling ambient temperature and humidity (Brown-Brandl et al., 2011). Two replicates (environmental chambers B and D) were used for the hot treatment (HOT) at $30^{\circ} \mathrm{C}$ with a $12^{\circ} \mathrm{C}$ dew point, and two replicates (environmental chambers $\mathrm{A}$ and $\mathrm{C}$ ) were used for the cool treatment $(\mathrm{COOL})$ at $15^{\circ} \mathrm{C}$ with a $10^{\circ} \mathrm{C}$ dew point, with each chamber maintaining a steady ambient temperature and humidity level throughout the study. Each $1.6 \mathrm{~m} \times 1.6 \mathrm{~m} \times 2.44 \mathrm{~m}$ environmental chamber held eight lab-scale bedded packs, two of each bedding material treatment, during each of four 6-week periods, creating $16 \mathrm{ex}$ perimental units per bedding treatment. During the first three weeks, before being placed in their respective environmental chambers, the bedded packs were all stored in a common room at constant temperature of $18^{\circ} \mathrm{C}$.

\section{Gas SAMPle Collection}

Sample collections were completed on Tuesday (chambers $\mathrm{A}$ and $\mathrm{B}$ ) and Wednesday (chambers $\mathrm{C}$ and $\mathrm{D}$ ) before feces, urine, and fresh bedding were added to the bedded packs. Ammonia, $\mathrm{CH}_{4}, \mathrm{CO}_{2}, \mathrm{~N}_{2} \mathrm{O}$, and $\mathrm{H}_{2} \mathrm{~S}$ flux were measured using eight stainless steel hemispherical flux chambers with an overall surface area of $640 \mathrm{~cm}^{2}$ and $7 \mathrm{~L}$ volume (Spiehs, 2018). Air was collected from the headspace above each lab-scale bedded pack on days 28, 35, and 42. Flux samples from the air above the bedded packs were collected as described previously by Spiehs (2018) and Spiehs et al. (2019) for $\mathrm{NH}_{3}, \mathrm{H}_{2} \mathrm{~S}$, and $\mathrm{GHG}$ analyses.

At the initiation of gas sampling, one flux chamber was placed on top of each lab-scale bedded pack. Centered within the headspace, approximately $70 \mathrm{~mm}$ above the bedded pack surface, was a $40 \mathrm{~mm}, 12 \mathrm{~V}$ axial-flow fan moving approximately $130 \mathrm{~L} \mathrm{~min}^{-1}$ of airflow from the surface to the top of the flux chamber (Spiehs et al., 2019). An elastic rubber skirt, $61 \mathrm{~cm}$ square with a $22.9 \mathrm{~cm}$ diameter hole in the center, was installed over the flux chamber to form a seal on top of the bedded pack container when the flux chamber was placed on the container for air sampling (Spiehs, 2018). Inert tubing $(0.64 \mathrm{~cm}$ diameter) was attached to the flux chamber using inert compression fittings (Spiehs, 2018). The inert tubing was attached to a gas sampling manifold that fed into the air sampling equipment (Spiehs, 2018).

The gas sampling system was controlled by a $24 \mathrm{~V}$ programmable logic relay, which signaled multi-positional three-way solenoids to open and close one of eight air inlet lines on the gas sampling manifold (Spiehs, 2018). One line was opened at a time to allow air sampling from each bedded pack (Spiehs, 2018). Ambient air was flushed through the tubing at a rate of $5 \mathrm{~L} \mathrm{~min}^{-1}$ for $30 \mathrm{~min}$, followed by $1 \mathrm{~L} \mathrm{~min}^{-1}$ air sampling for 20 min per bedded pack (Spiehs, 2018). Only sampling data from minutes 8 to 20 were analyzed to guarantee a representative sample from the tubing. The initial 7 min of sampling data were removed to allow steady state to be reached.

The equipment used for analyses of the air flux samples was as previously described by Spiehs (2018). Hydrogen sulfide air flux samples were analyzed using a Thermo Fisher 450i hydrogen sulfide/sulfur dioxide/combined sulfur pulsed fluorescence gas analyzer (Thermo Fisher, Waltham, Mass.). Ammonia emissions were determined using a Thermo Fisher 17i ammonia chemiluminescent gas analyzer, and $\mathrm{CH}_{4}$ was measured with a Thermo Fisher 55i direct methane and non-methane hydrocarbon backflush gas chromatograph. The remaining GHGs $\left(\mathrm{N}_{2} \mathrm{O}\right.$ and $\left.\mathrm{CO}_{2}\right)$ were measured using an Innova 1412 photoacoustic gas monitor (LumaSense Technologies, Santa Clara, Cal.).

\section{Bedded Pack Sample Collection}

Chemical and physical properties of the bedded packs were measured weekly before the addition of bedding, urine, and fecal material. A representative sample of approximately $20 \mathrm{~g}$ was collected at the center of each bedded pack approximately $7.6 \mathrm{~cm}$ below the surface and diluted with distilled 
water at a 1:2 mass ratio, followed by $\mathrm{pH}$ determination using a $\mathrm{pH} / \mathrm{mV} /$ temperature meter (IQ150, Spectrum Technologies, Inc., Plainsfield, Ill.). Pack temperature was also measured in the center of each pack at approximately $7.6 \mathrm{~cm}$ below the surface using the IQ150 $\mathrm{pH} / \mathrm{mV} /$ temperature meter. Bedded pack height was measured prior to air sample collection to determine the pack depth. Mixing of the bedding, feces, and urine each week prevented a sampling hole from developing in the middle of the bedded packs.

The free air space percentage was determined through water displacement, which was measured on the final day of the study, as described by Spiehs et al. (2012, 2014a, 2014b). Air displacement volume provides a rough estimate of aerobic/anaerobic status within a bedded pack, with greater air displacement being more aerobic.

\section{Statistical ANALYSIS}

Data were analyzed as a $2 \times 4$ factorial with repeated measures in time using the GLIMMIX procedure of SAS (SAS Institute, Cary, N.C.). The model included the effects of bedding material, temperature, age of bedded pack, replicate, period, bedding material $\times$ temperature, bedding material $\times$ age of bedded pack, and bedding material $\times$ temperature $\times$ age of bedded pack. Covariate structure was tested using the Toeplitz, autoregressive, and compound symmetry variance components to find the lowest Akaike information criterion (AIC) value. Compound symmetry was found to provide the lowest AIC value. Fisher's least significant difference test was used for means separation when significant differences were detected in the least squares means. The experimental unit was bedded pack. Individual treatments represent bedding material type, temperature, and age of bedded pack. Differences were considered significant when $p<0.05$ and tendencies at $\mathrm{p}$-values ranging from $\mathrm{p}=0.05$ to $\mathrm{p}<0.10$.

\section{RESULTS AND DisCUSSION}

\section{Physical Properties}

A significant $(p=0.0027)$ interaction for bedding material by temperature was observed for the $\mathrm{pH}$ of the bedded packs (fig. 3). Bean stover (BS) bedded packs maintained at COOL temperatures had significantly $(\mathrm{p}<0.0001)$ lower $\mathrm{pH}$ compared to COOL-CS, COOL-PC, and COOL-WS (7.6, $7.9,8.1$, and $8.3 \mathrm{pH}$, respectively). Meanwhile, COOL-WS bedded pack $\mathrm{pH}$ was significantly $(\mathrm{p}=0.0124)$ greater than the other COOL treatments. Bedded packs with the HOT-PC and HOT-WS treatments had similar $\mathrm{pH}$, which was higher than the $\mathrm{pH}$ of the bedded packs with the HOT-BS and HOTCS treatments. Both HOT-BS and HOT-PC had significantly ( $p<0.0001$ and $\mathrm{p}=0.0014$, respectively) greater $\mathrm{pH}$ compared to the COOL treatments with the same bedding materials, while HOT-CS and HOT-WS had $\mathrm{pH}$ values similar to the same bedding materials in the COOL treatments.

No significant multi-variable interactions were observed for bedded pack temperature (table 1). Wheat straw bedded packs had significantly $(\mathrm{p}<0.0001)$ greater temperatures compared to the other three bedding materials, while BS maintained the lowest bedded pack temperature $\left(23.1^{\circ} \mathrm{C}\right.$ $\pm 0.9^{\circ} \mathrm{C}$ ). Bedded pack temperatures did not change significantly over time. Bedded packs in the COOL treatments had average temperatures of $18.8^{\circ} \mathrm{C} \pm 0.2^{\circ} \mathrm{C}$. Similar bedded pack temperatures that were approximately $2^{\circ} \mathrm{C}$ to $3^{\circ} \mathrm{C}$ greater than the ambient temperature were reported previously when lab-scale bedded packs were housed at

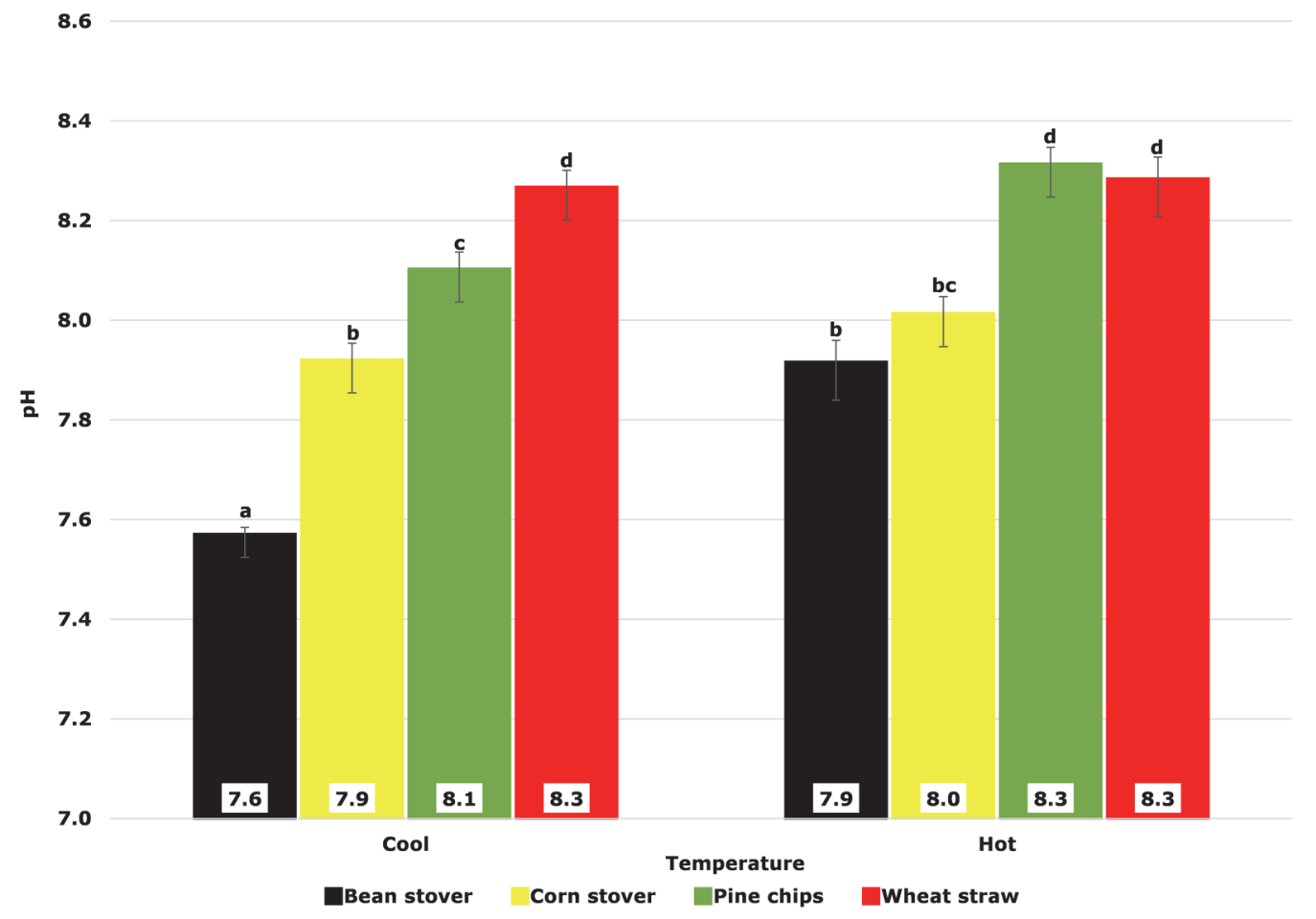

Figure 3. Average pH of lab-scale bedded packs stored at cool $\left(15^{\circ} \mathrm{C}\right)$ or hot $\left(30^{\circ} \mathrm{C}\right)$ temperatures and containing bean stover, corn stover, pine wood chips, or wheat straw over four 6-week periods. Values are least square means; error bars indicate standard errors. Within treatments, least square means with different letters are significantly different $(p<0.05)$. For bedding material $\times$ temperature interaction, $p=0.0027$. 
Table 1. Bedded pack pH, temperature, height, and free air space from lab-scale bedded packs containing bean stover, corn stover, pine wood chips, and wheat straw at 42 days. ${ }^{[a]}$

\begin{tabular}{|c|c|c|c|c|c|}
\hline \multicolumn{2}{|c|}{ Treatment Factors } & $\begin{array}{c}\text { Bedded Pack } \\
\mathrm{pH}\end{array}$ & $\begin{array}{c}\text { Bedded Pack } \\
\text { Temperature }\left({ }^{\circ} \mathrm{C}\right)\end{array}$ & $\begin{array}{c}\text { Bedded Pack } \\
\text { Height }(\mathrm{cm})\end{array}$ & $\begin{array}{c}\text { Free Air Space } \\
(\%)\end{array}$ \\
\hline \multirow[t]{4}{*}{ Bedding } & Bean stover & $7.7 \pm 0.0$ & $23.1 \pm 0.9 \mathrm{a}$ & $12.4 \pm 0.2 \mathrm{a}$ & $19.4 \pm 1.3$ \\
\hline & Corn stover & $8.0 \pm 0.0$ & $24.2 \pm 0.8 \mathrm{~b}$ & $14.3 \pm 0.3 \mathrm{c}$ & $27.4 \pm 1.1$ \\
\hline & Pine wood chips & $8.2 \pm 0.0$ & $23.7 \pm 0.8 \mathrm{ab}$ & $13.8 \pm 0.3 \mathrm{~b}$ & $29.5 \pm 1.6$ \\
\hline & Wheat straw & $8.3 \pm 0.0$ & $26.6 \pm 0.9 \mathrm{c}$ & $19.2 \pm 0.4 \mathrm{~d}$ & $43.4 \pm 0.8$ \\
\hline \multirow[t]{2}{*}{ Temperature } & $\operatorname{Cool}\left(15^{\circ} \mathrm{C}\right)$ & $8.0 \pm 0.0$ & $18.8 \pm 0.2 \mathrm{~A}$ & $15.0 \pm 0.3$ & $27.3 \pm 1.8$ \\
\hline & Hot $\left(30^{\circ} \mathrm{C}\right)$ & $8.1 \pm 0.0$ & $30.0 \pm 0.3 \mathrm{~B}$ & $14.8 \pm 0.3$ & $32.6 \pm 1.6$ \\
\hline \multirow[t]{3}{*}{ Age of bedded pack } & Week 4 & $8.0 \pm 0.0$ & $24.3 \pm 0.8$ & $13.4 \pm 0.4 \mathrm{x}$ & - \\
\hline & Week 5 & $8.1 \pm 0.0$ & $24.8 \pm 0.8$ & $14.9 \pm 0.4 \mathrm{y}$ & - \\
\hline & Week 6 & $7.9 \pm 0.0$ & $24.2 \pm 0.8$ & $16.4 \pm 0.4 \mathrm{z}$ & - \\
\hline \multirow{7}{*}{$\begin{array}{r}\text { Be } \\
\text { Beddi } \\
\text { Temper } \\
\text { Bedding } \times \text { Te }\end{array}$} & & - & $\mathrm{p}<0.0001$ & p $<0.0001$ & - \\
\hline & rature & - & $\mathrm{p}<\mathbf{0 . 0 0 0 1}$ & NS & - \\
\hline & Ided pack & - & NS & $\mathrm{p}<\mathbf{0 . 0 0 0 1}$ & - \\
\hline & emperature & $\mathbf{p}=\mathbf{0 . 0 0 2 7}$ & NS & NS & $p=0.0295$ \\
\hline & of bedded pack & NS & NS & NS & - \\
\hline & e of bedded pack & NS & NS & NS & - \\
\hline & $\times$ Age of bedded pack & NS & NS & NS & - \\
\hline \multicolumn{6}{|c|}{$\begin{array}{l}\text { Treatments consisted of temperature }\left(15^{\circ} \mathrm{C} \text { or } 30^{\circ} \mathrm{C}\right) \text {, bedding (bean stover, corn stover, pine wood chips, or wheat straw), and age of the bedded } \\
\text { pack }(4,5 \text {, or } 6 \text { weeks old). Four } 6 \text {-week experiments were conducted with four bedding material replicates per experiment }(n=128) \text {. Values are } \\
\text { least square means with standard errors. Within a column, lowercase letters }(\mathrm{a}, \mathrm{b}, \mathrm{c}) \text { indicate significant differences }(\mathrm{p}<0.05) \text { among bedding treat- } \\
\text { ments, uppercase letters }(\mathrm{A}, \mathrm{B}, \mathrm{C}) \text { indicate significant differences }(\mathrm{p}<0.05) \text { among temperature treatments, and lowercase letters }(\mathrm{x}, \mathrm{y}, \mathrm{z}) \text { indicate } \\
\text { significant differences }(\mathrm{p}<0.05) \text { among age of bedded pack treatments. Significant effects }(\mathrm{p}<0.05) \text { are shown in bold. }\end{array}$} \\
\hline
\end{tabular}

approximately $18^{\circ} \mathrm{C}$ (Spiehs et al., 2013, 2014a, 2017). The slight increase in bedded pack temperature over ambient temperature is likely the result of heat generated by microbial activity. Conversely, bedded packs in the HOT treatments had average temperatures of $30.0^{\circ} \mathrm{C} \pm 0.3^{\circ} \mathrm{C}$, which was identical to the ambient temperature.

When comparing bedding material types, the increases in bedded pack temperatures mirrored the increases in bedded pack height (table 1). Bean stover bedded packs were significantly $(\mathrm{p}<0.0001)$ shorter $(12.4 \pm 0.2 \mathrm{~cm})$ across bedding materials, while WS bedded packs were significantly ( $p<$ $0.0001)$ taller $(19.2 \pm 0.4 \mathrm{~cm})$ than the other three bedding materials. Bedded packs maintained at HOT and COOL temperatures were similar in height $(14.8 \pm 0.3$ vs. $15.0 \pm 0.3 \mathrm{~cm})$. As anticipated, bedded pack height significantly ( $\mathrm{p}<$ 0.0001 ) increased over time as bedding material was added throughout the 6-week study.

Free air space gives an indication of the bedded pack microbial environment, with lower free air space indicating greater potential for an anaerobic environment. The percentage of free air space was 2 to 4 times greater compared to previous free air space percentages from lab-scale bedded packs with similar bedding materials (Spiehs et al., 2013, 2014a). A significant $(p=0.0295)$ interaction for bedding material by temperature was observed for free air space as a percentage of total mass of the bedded pack (fig. 4). Free air space for COOL-WS and HOT-WS bedded packs was significantly $(\mathrm{p}<0.0001)$ greater than for the other three bedding materials within their respective temperature treatments, while COOL-BS and HOT-BS bedded packs were significantly $(p<0.0001)$ lower in free air space compared to the other bedding materials within their respective temperature treatments. Across all treatments, HOT-WS had the greatest free air space at $44.9 \%$ significantly, while COOLBS had the lowest at $16.0 \%$ significantly. Spiehs et al. (2013) reported that BS and WS had larger free air space in labscale bedded packs compared to CS and wood chips (15.8\%,
$14.0 \%, 8.8 \%$, and $7.7 \%$, respectively). Different bedding material batches between studies may have resulted in variable bedding material process lengths from one lab-scale bedded pack study to the next, contributing to some of the free air space differences observed.

\section{Ammonia}

A significant $(\mathrm{p}=0.0094)$ interaction between bedding material and temperature was observed for $\mathrm{NH}_{3}$ flux (table 2). Ammonia flux from BS, CS, and WS was significantly greater at HOT temperatures than at COOL temperatures (fig. 5). Ammonia flux from PC was similar for HOT and COOL temperatures (303.7 and $281.4 \mathrm{mg} \mathrm{m}^{-2} \mathrm{~h}^{-1}$ ). The $\mathrm{NH}_{3}$ flux above COOL-CS was lowest $\left(122.2 \mathrm{mg} \mathrm{m}^{-2} \mathrm{~h}^{-1}\right)$ of all treatments, while HOT-WS had the greatest $\left(372.9 \mathrm{mg} \mathrm{m}^{-}\right.$ $\left.{ }^{2} \mathrm{~h}^{-1}\right) \mathrm{NH}_{3}$ flux. Lower $\mathrm{NH}_{3}$ flux from the COOL treatments was expected, as $\mathrm{NH}_{3}$ volatilization increases as temperature increases (Ayadi et al., 2015; Koenig and McGinn, 2016). In a Nebraska open feedlot system, seasonal nitrogen loss during warmer summer months was $155 \mathrm{~g} \mathrm{head}^{-1} \mathrm{~d}^{-1}$ compared to $92 \mathrm{~g} \mathrm{head}^{-1} \mathrm{~d}^{-1}$ during colder winter months (Koelsch et al., 2018). Unused dietary nitrogen from cattle is primarily excreted as urea in urine (Varel, 1997; Bierman et al., 1999; Cole et al., 2005). As temperature increases, urease activity increases the rate of conversion of urea to $\mathrm{NH}_{3}$ in manure (Moraes et al., 2017). Spiehs et al. (2011) reported similar findings from beef deep-bedded mono-slope facilities, where $\mathrm{NH}_{3}$ concentrations in the air were $1694.6 \pm 49.4 \mathrm{ppm}$ when the ambient temperature was at or above $20.6^{\circ} \mathrm{C}$, compared to $252.1 \pm 92.0 \mathrm{ppm}$ when the ambient temperature was at or below $0^{\circ} \mathrm{C}$.

Ammonia emissions were potentially higher for the PC bedding treatments regardless of the temperature because of increased urine absorption, which allowed a greater percentage of the surface area of the urine-soaked bedding material to be exposed to air movement. When urine is not absorbed by the bedding material, it drains through to the bottom of 


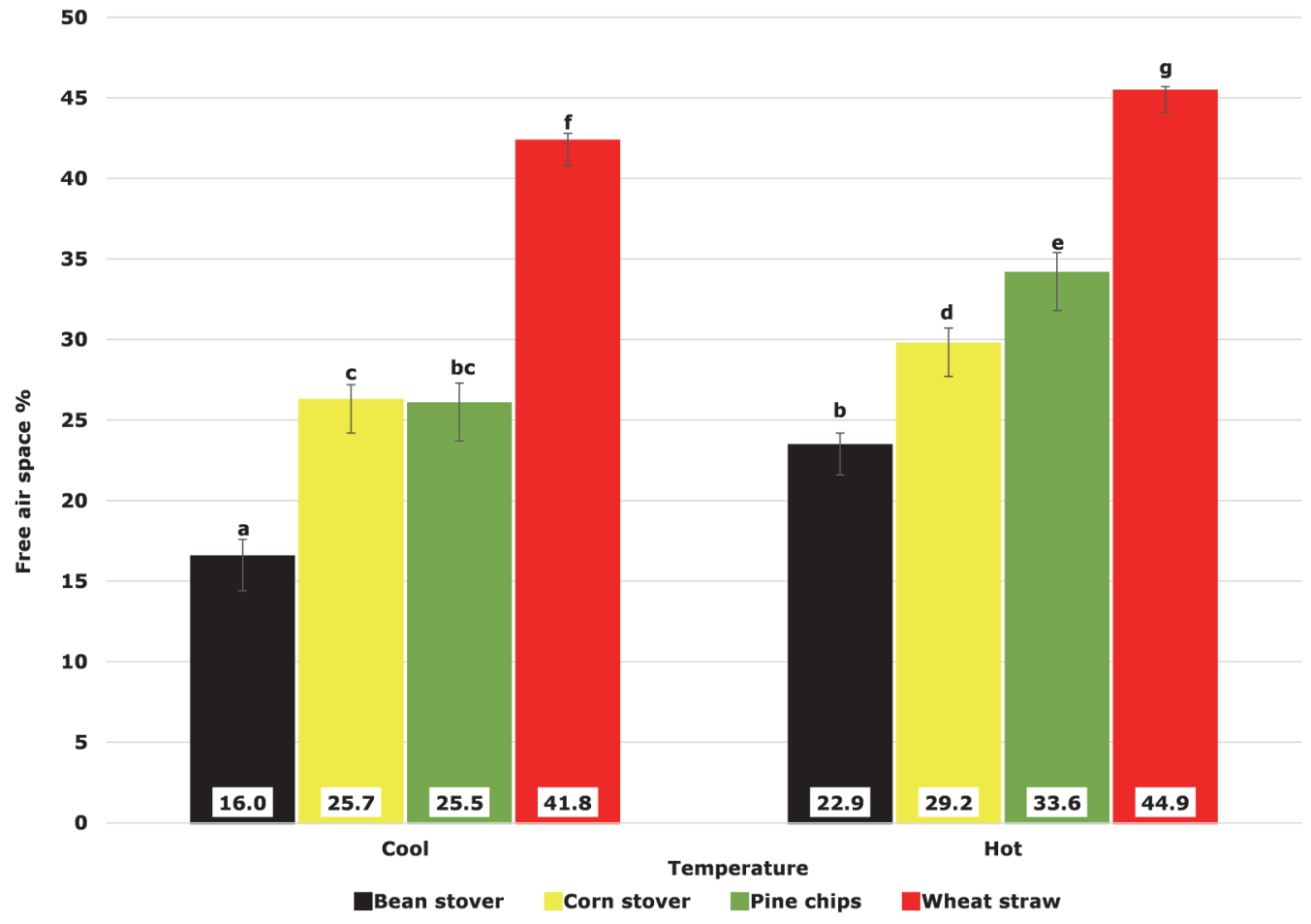

Figure 4. Free air space percentage of lab-scale bedded packs stored at cool $\left(15^{\circ} \mathrm{C}\right)$ or hot $\left(30^{\circ} \mathrm{C}\right)$ temperatures and containing bean stover, corn stover, pine wood chips, or wheat straw at the end of the 6-week study. Values are least square means; error bars indicate standard errors. Least square means with different letters are significantly different $(p<0.05)$. For bedding material $\times$ temperature interaction, $p=0.0295$.

Table 2. Interaction p-values for ammonia $\left(\mathrm{NH}_{3}\right)$, greenhouse gas $\left(\mathrm{CH}_{4}, \mathrm{CO}_{2}\right.$, and $\left.\mathrm{N}_{2} \mathrm{O}\right)$, and hydrogen sulfide $\left(\mathrm{H}_{2} \mathrm{~S}\right)$ flux in the headspace air above lab-scale bedded packs containing bean stover, corn stover, pine wood chips, or wheat straw. ${ }^{[\mathrm{a}]}$

\begin{tabular}{|c|c|c|c|c|c|}
\hline Treatment Factors & $\mathrm{NH}_{3}$ & $\mathrm{H}_{2} \mathrm{~S}$ & $\mathrm{CH}_{4}$ & $\mathrm{CO}_{2}$ & $\mathrm{~N}_{2} \mathrm{O}$ \\
\hline Bedding & $<0.0001$ & $<0.0001$ & $<0.0001$ & $<0.0001$ & $<0.0001$ \\
\hline Temperature & $<0.0001$ & $<0.0001$ & $<0.0001$ & $<0.0001$ & $<0.0001$ \\
\hline Age of bedded pack & 0.0063 & 0.2310 & $<0.0001$ & 0.1872 & $<0.0001$ \\
\hline Bedding $\times$ Temperature & 0.0094 & $<0.0001$ & 0.0005 & 0.0189 & 0.1175 \\
\hline Bedding $\times$ Age of bedded pack & 0.5461 & 0.7644 & 0.0020 & 0.4823 & 0.8328 \\
\hline Temperature $\times$ Age of bedded pack & 0.4695 & 0.0357 & $<0.0001$ & 0.3922 & 0.1028 \\
\hline Bedding $\times$ Temperature $\times$ Age of bedded pack & 0.9404 & 0.6385 & 0.0422 & 0.8783 & 0.9465 \\
\hline
\end{tabular}

[a] Treatments consisted of temperature $\left(15^{\circ} \mathrm{C}\right.$ or $\left.30^{\circ} \mathrm{C}\right)$, bedding (bean stover, corn stover, pine wood chips, or wheat straw), and age of the bedded pack $(4,5$, or 6 weeks). Four 6 -week experiments were conducted with four bedding material replicates per experiment $(n=128)$. Significant effects $(\mathrm{p}<0.05)$ are shown in bold.

the bedded pack, where volatilization is limited due to less air turbulence (Misselbrook and Powell, 2005). Corn stover consistently provided some of the lowest $\mathrm{NH}_{3}$ emissions in both COOL and HOT treatments, suggesting that CS is a viable bedding option to help reduce $\mathrm{NH}_{3}$ volatilization.

\section{HYDROGEN SULFIDE}

A significant $(\mathrm{p}<0.0001)$ interaction between bedding material and temperature was observed for $\mathrm{H}_{2} \mathrm{~S}$ flux in the headspace above the bedded packs (table 2). Hydrogen sulfide flux from bedding materials at COOL temperatures was greater for all treatments compared to HOT temperatures. The greatest flux $\left(90.3 \mu \mathrm{g} \mathrm{m}^{-2} \mathrm{~h}^{-1}\right)$ was produced by COOLBS, while HOT-WS produced the lowest flux at $5.6 \mu \mathrm{g} \mathrm{m}^{-2}$ $\mathrm{h}^{-1}$ (fig. 6). The $\mathrm{H}_{2} \mathrm{~S}$ flux from HOT-WS was not statistically different from HOT-PC, HOT-CS, HOT-BS, and COOLWS $\left(15.2,15.9,17.3\right.$, and $20.7 \mu \mathrm{g} \mathrm{m}^{-2} \mathrm{~h}^{-1}$, respectively).

Additionally, a significant $(\mathrm{p}=0.0357)$ interaction between temperature and age of the bedded pack was observed for $\mathrm{H}_{2} \mathrm{~S}$ flux in the headspace above the bedded packs (fig. 7). Bedded packs stored at HOT temperatures had significant reductions in $\mathrm{H}_{2} \mathrm{~S}$ flux as the bedded packs increased in age from week 4 to week 6 (25.8 vs. $4.2 \mu \mathrm{g} \mathrm{m}^{-2} \mathrm{~h}^{-1}$, respectively). Bedded packs stored at COOL temperatures were similar across all weeks, with week 6 having the highest flux $\left(50.2 \mu \mathrm{g} \mathrm{m}^{-2} \mathrm{~h}^{-1}\right)$. At week $4, \mathrm{H}_{2} \mathrm{~S}$ flux was similar between COOL and HOT treatments (41.7 and $25.8 \mu \mathrm{g} \mathrm{m}^{-2}$ $\mathrm{h}^{-1}$, respectively). At weeks 5 and 6 , bedded packs in COOL treatments produced significantly $(\mathrm{p}=0.0013)$ greater flux compared to HOT treatments.

Previously, Arogo et al. (1999) reported that $\mathrm{H}_{2} \mathrm{~S}$ emissions from liquid swine manure were reduced as air temperature increased from $15^{\circ} \mathrm{C}$ to $35^{\circ} \mathrm{C}$. However, $\mathrm{H}_{2} \mathrm{~S}$ emissions are typically affected by temperature in the opposite manner. Cortus et al. (2013) observed a significant increase in $\mathrm{H}_{2} \mathrm{~S}$ concentrations from mono-slope cattle facilities as temperature increased. As temperature increases, microbial activity increases, which stimulates $\mathrm{H}_{2} \mathrm{~S}$ production (Cortus et al., 


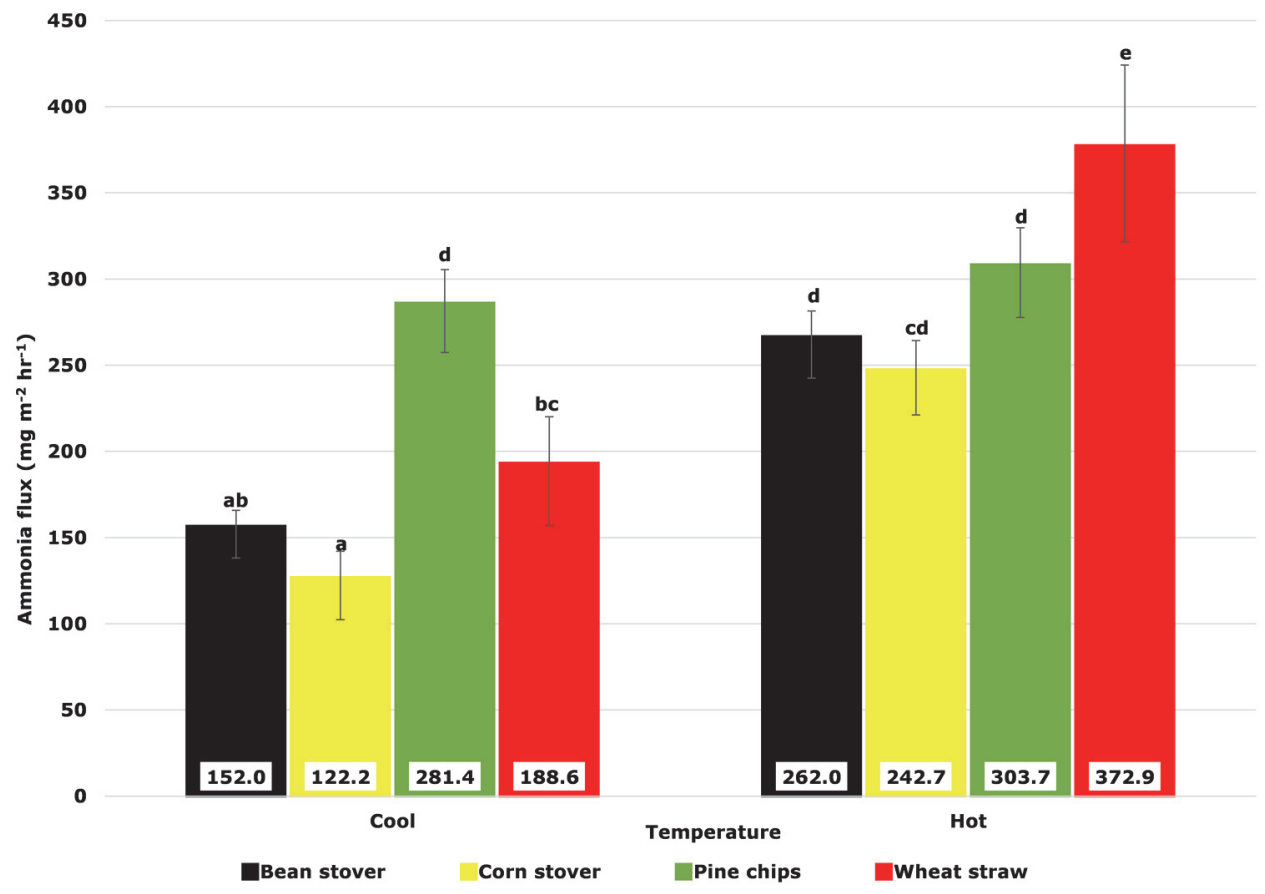

Figure 5. Average ammonia flux $\left(\mathrm{mg} \mathrm{m}^{-2} \mathrm{~h}^{-1}\right)$ in headspace air above lab-scale bedded packs stored at cool $\left(15^{\circ} \mathrm{C}\right)$ or hot $\left(30^{\circ} \mathrm{C}\right)$ temperatures and containing bean stover, corn stover, pine wood chips, or wheat straw. Values are least square means; error bars indicate standard errors. Least square means with different letters are significantly different $(p<0.05)$. For bedding material $\times$ temperature interaction, $p=0.0094$.

120

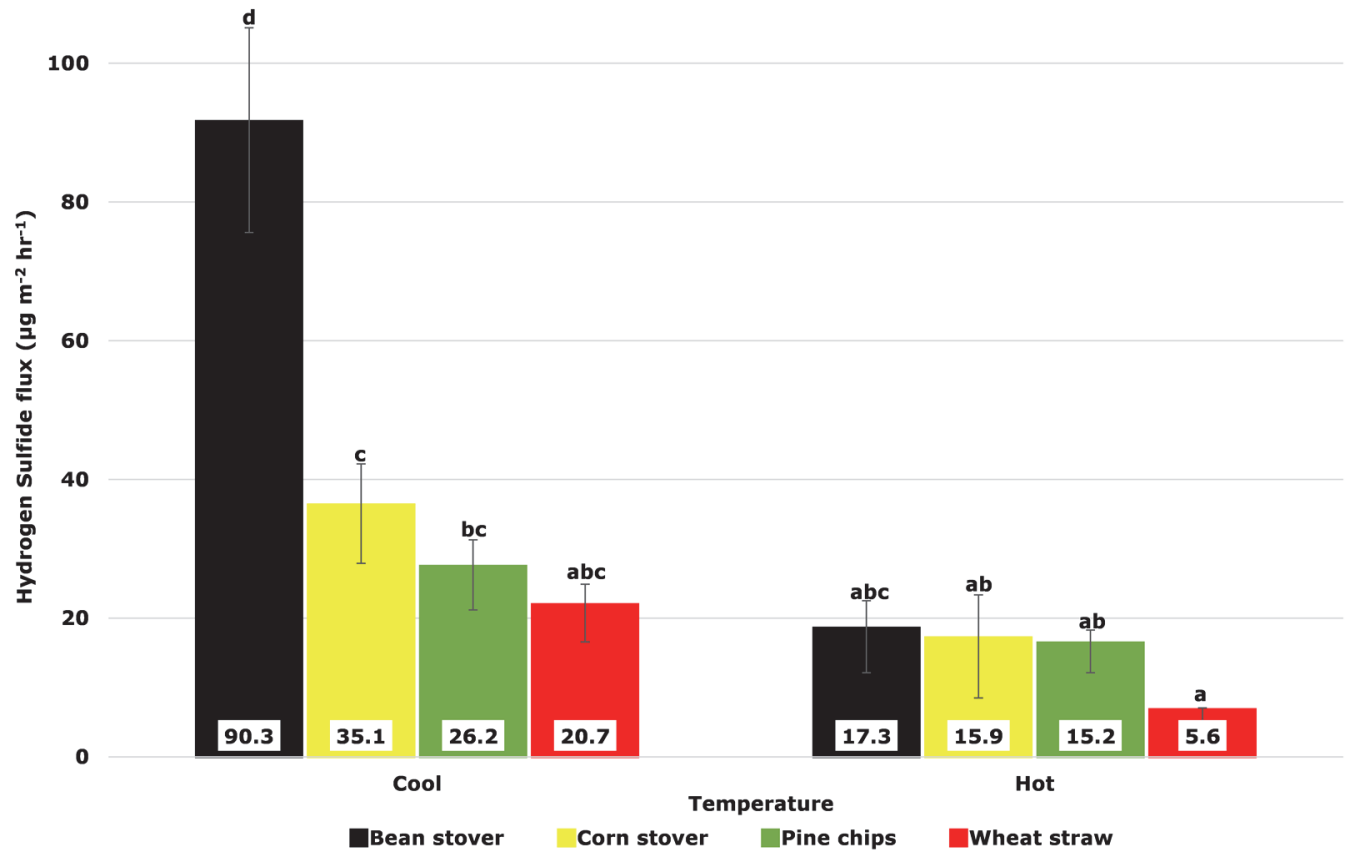

Figure 6. Average hydrogen sulfide flux $\left(\mu \mathrm{g} \mathrm{m}^{-2} \mathrm{~h}^{-1}\right)$ in headspace air above lab-scale bedded packs stored at cool $\left(15^{\circ} \mathrm{C}\right)$ or hot $\left(30^{\circ} \mathrm{C}\right)$ temperatures and containing bean stover, corn stover, pine wood chips, or wheat straw. Values are least square means; error bars indicate standard errors. Least square means with different letters are significantly different $(p<0.05)$. For bedding material $\times$ temperature interaction, $p<0.0001$.

2014). Additionally, Andriamanohiarisoamanana et al. (2015) reported an exponential increase in $\mathrm{H}_{2} \mathrm{~S}$ concentrations from liquid dairy manure as temperature increased from $8^{\circ} \mathrm{C}$ to $28^{\circ} \mathrm{C}$. In the current study, WS produced the lowest $\mathrm{H}_{2} \mathrm{~S}$ flux of all bedding materials across both HOT and COOL treatments (20.7 and $5.6 \mu \mathrm{g} \mathrm{m}^{-2} \mathrm{~h}^{-1}$, respectively).
Bedded packs with WS had the highest pack height (19.2 $\pm 0.4 \mathrm{~cm}$ ), which indicates less compaction, more free air space, and potentially a more aerobic environment that is therefore less conducive to anaerobic $\mathrm{H}_{2} \mathrm{~S}$ production. Conversely, BS bedded packs had the lowest heights (12.4 $\pm 0.2 \mathrm{~cm}$ ) at the conclusion of the 6-week study (table 1 ), 


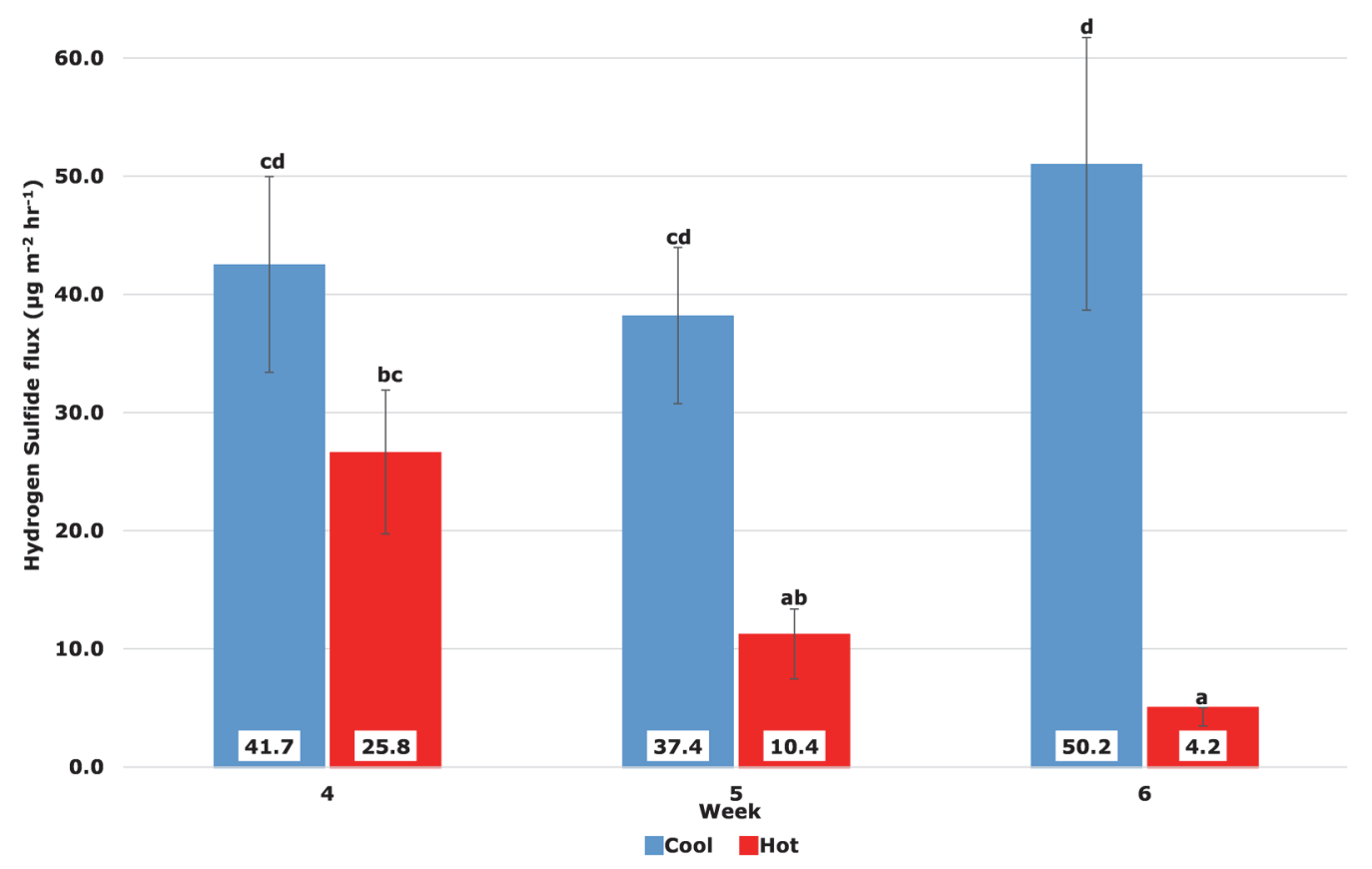

Figure 7. Average hydrogen sulfide flux $\left(\mu \mathrm{g} \mathrm{m}^{-2} \mathrm{~h}^{-1}\right)$ in headspace air above lab-scale bedded packs stored at $\operatorname{cool}\left(15^{\circ} \mathrm{C}\right)$ or hot $\left(30^{\circ} \mathrm{C}\right)$ temperatures and containing bean stover, corn stover, pine wood chips, or wheat straw. Values are least square means; error bars indicate standard errors. Least square means with different letters are significantly different $(p<0.05)$. For temperature $\times$ age of bedded pack interaction, $p=0.0357$.

indicating increased compaction, less free air space, and a greater anaerobic microbial environment that contributed to the high $\mathrm{H}_{2} \mathrm{~S}$ flux from COOL-BS bedded packs.

In this study, low $\mathrm{pH}$ appears to have been the main influence on increased $\mathrm{H}_{2} \mathrm{~S}$ production, instead of the increase in temperature. The COOL-BS bedded packs had significantly lower $\mathrm{pH}(7.6 \pm 0.0 \mathrm{pH})$ across all bedding materials and temperatures (fig. 4). Low $\mathrm{pH}(<7.0)$ favors $\mathrm{H}_{2} \mathrm{~S}$ production (Linderholm et al., 2008). Previous research demonstrated a $285 \%$ increase in $\mathrm{H}_{2} \mathrm{~S}$ concentrations when the $\mathrm{pH}$ of stored liquid dairy manure decreased from 7.32 to 6.82 (Andriamanohiarisoamanana et al., 2015). Yongsiri et al. (2004) reported that the effect of higher temperature on increased $\mathrm{H}_{2} \mathrm{~S}$ production was eliminated as the $\mathrm{pH}$ of wastewater sewage was reduced to 4.5. In the current study, the BS bedded packs were observed to have more standing liquid compared to the other bedded packs. Standing liquid provides more surface area for exposure to air movement, increasing $\mathrm{H}_{2} \mathrm{~S}$ volatilization and is a likely indication of anaerobic conditions in the bedding material.

\section{GREENHOUSE GASES}

A significant $(p=0.0422)$ interaction of bedding material, temperature, and age of bedded pack was observed for $\mathrm{CH}_{4}$ flux in the bedded pack headspace (fig. 8). At week $4, \mathrm{CH}_{4}$ concentrations in the headspace above the bedded packs were similar across all treatments. At week 5 , all the bedded packs in the COOL treatments and the packs in the HOT-BS, HOT-PC, and HOT-WS treatments produced similar yet minimal flux compared to HOT-CS. At week 6, HOT-BS and HOT-CS had significantly greater $\mathrm{CH}_{4}$ flux (10.48 and $12.59 \mathrm{mg} \mathrm{m}^{-2} \mathrm{~h}^{-1}$, respectively) compared to all other treatments. HOT-BS and HOT-CS also had significantly greater $\mathrm{CH}_{4}$ flux during week 6 compared to the previous weeks. Methane production is a result of anaerobic degradation of organic matter (Bryant, 1979). The BS and CS bedded packs had less free air space and lower heights at week 6 compared to the other treatments, which likely created an anaerobic environment conducive to $\mathrm{CH}_{4}$ production (table 1). As expected, the bedded packs in the HOT treatments were significantly warmer than the bedded packs in the COOL treatments $\left(30.0^{\circ} \mathrm{C}\right.$ vs. $18.8^{\circ} \mathrm{C}$, respectively) over the course of the study. The ideal temperature for mesophilic anaerobic $\mathrm{CH}_{4}$ production from livestock manure is $35^{\circ} \mathrm{C}$ to $37^{\circ} \mathrm{C}$ (Sakar et al., 2009). Methane emissions from feedlot manure have been linked to increases in ambient temperature (Jarvis et al., 1995; Woodbury et al., 2018). Woodbury et al. (2018) reported that the mean $\mathrm{CH}_{4}$ flux from feedlot manure increased exponentially from 0.004 to $0.572 \mathrm{~g} \mathrm{~m}^{-2} \mathrm{~d}^{-1}$ as the temperature increased from $5^{\circ} \mathrm{C}$ to $35^{\circ} \mathrm{C}$.

A significant $(\mathrm{p}=0.0189)$ interaction of bedding material and temperature was observed for $\mathrm{CO}_{2}$ flux in the bedded pack headspace (fig. 9). Within the COOL and HOT treatments, $\mathrm{CO}_{2}$ flux was significantly greater above WS (9164 and $9990 \mathrm{mg} \mathrm{m}^{-2} \mathrm{~h}^{-1}$, respectively) than the other bedding materials. Carbon dioxide emission is considered an indicator of microbial activity within livestock manure (Woodbury et al., 2018). The production of $\mathrm{CO}_{2}$ is a result of aerobic respiration, which increases as temperature and aeration increase (Hao et al., 2001). When bedded packs are compacted or maintained at cold temperatures, aerobic respiration is reduced compared to more aerated or warmer bedded packs. In the current study, WS had greatest free air space in both HOT and COOL treatments $(44.9 \%$ and 


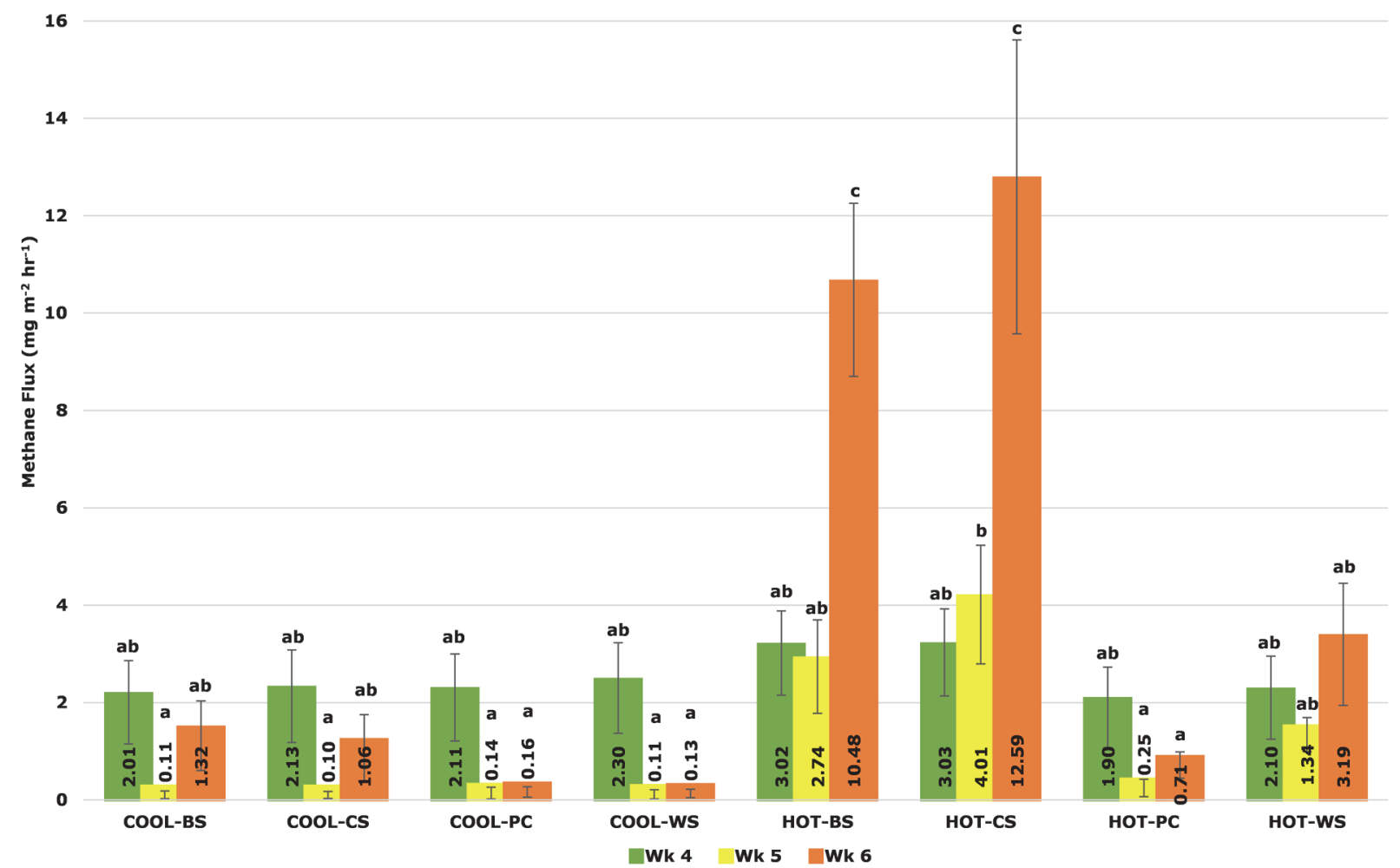

Figure 8. Average methane flux $\left(\mathrm{mg} \mathrm{m}^{-2} \mathrm{~h}^{-1}\right)$ over time in headspace air above lab-scale bedded packs stored at $\operatorname{cool}\left(15^{\circ} \mathrm{C}\right)$ or hot $\left(30^{\circ} \mathrm{C}\right)$ temperatures and containing bean stover, corn stover, pine wood chips, or wheat straw. Values are least square means; error bars indicate standard errors. Within treatments, least square means with different letters are significantly different $(p<0.05)$. For temperature $\times$ bedding material $\times$ age of bedded pack interaction, $p<0.0422$.

12000

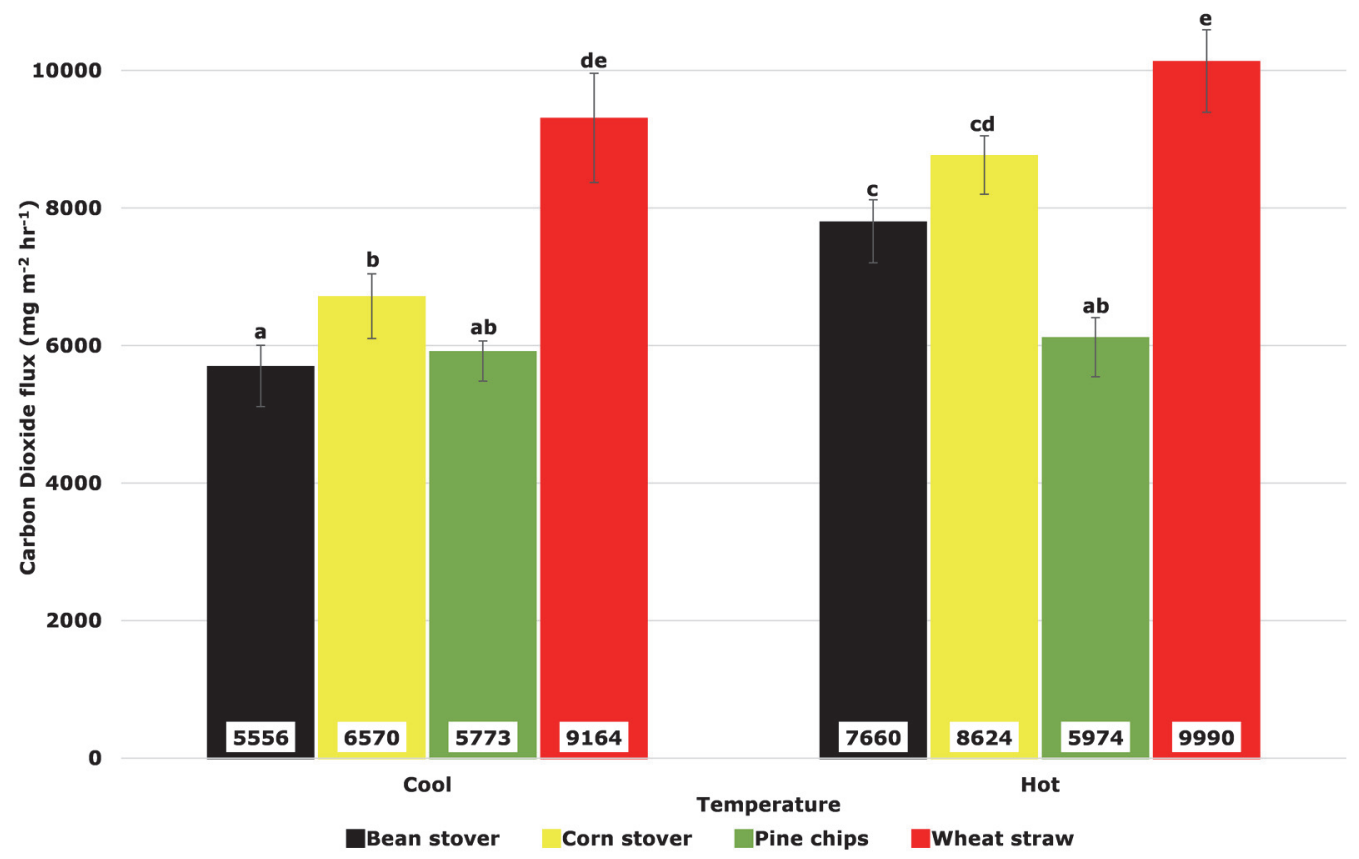

Figure 9. Average carbon dioxide flux $\left(\mathrm{mg} \mathrm{m}^{-2} \mathrm{~h}^{-1}\right)$ in headspace air above lab-scale bedded packs stored at $\operatorname{cool}\left(15^{\circ} \mathrm{C}\right)$ or hot $\left(30^{\circ} \mathrm{C}\right)$ temperatures and containing bean stover, corn stover, pine wood chips, or wheat straw. Values are least square means; error bars indicate standard errors. Least square means with different letters are significantly different $(p<0.05)$. For bedding material $\times$ temperature interaction, $p=0.0189$. 
$41.8 \%$, respectively; fig. 7) compared to the other bedding materials. Greater bedded pack height for WS provided greater oxygen $\left(\mathrm{O}_{2}\right)$ availability within the bedded pack, improving the aerobic environment for $\mathrm{CO}_{2}$ production. The production of $\mathrm{CO}_{2}$ is more sensitive to $\mathrm{O}_{2}$ availability than temperature. This could be the reason for the COOL-WS and HOT-WS treatments both having the greatest and similar $\mathrm{CO}_{2}$ flux compared to all other treatments. This was additionally observed in $\mathrm{CO}_{2}$ flux mirroring the free air space percentages (fig. 4). Additionally, COOL-PC and HOT-PC also had similar $\mathrm{CO}_{2}$ flux (5773 vs. $5974 \mathrm{mg} \mathrm{m}^{-2} \mathrm{~h}^{-1}$, respectively). Meanwhile, HOT-BS and HOT-CS had significantly greater $\mathrm{CO}_{2}$ flux compared to the same bedding materials at COOL temperatures. The BS and CS bedded packs had the lowest bedded pack heights, indicating greater compaction compared to WS and PC. With compaction limiting $\mathrm{O}_{2}$ availability for the $\mathrm{BS}$ and $\mathrm{CS}$ bedded packs, $\mathrm{CO}_{2}$ production was possibly driven by an increase in ambient temperature.

No significant multi-variable interactions were observed for $\mathrm{N}_{2} \mathrm{O}$ flux in the bedded pack headspace (table 2). Previous research by Ayadi et al. (2015) using CS and BS as bedding materials at $10^{\circ} \mathrm{C}$ and $40^{\circ} \mathrm{C}$ did not observe a significant interaction between bedding material, ambient temperature, and age of the bedded pack for $\mathrm{N}_{2} \mathrm{O}$ over a 6-week study. In the current study, $\mathrm{N}_{2} \mathrm{O}$ concentrations ranged from 0.029 to $0.808 \mathrm{mg} \mathrm{m}^{-2} \mathrm{~h}^{-1}$ across all bedded packs, which is similar to the $\mathrm{N}_{2} \mathrm{O}$ flux values reported by Spiehs et al. (2014b, 2016, 2019). Significant $(\mathrm{p}<0.0001)$ differences in $\mathrm{N}_{2} \mathrm{O}$ flux across bedding material types were observed (fig. 10). Bedded packs containing WS or $\mathrm{PC}$ has similar $\mathrm{N}_{2} \mathrm{O}$ flux, which was significantly higher than the $\mathrm{N}_{2} \mathrm{O}$ flux from bedded packs containing BS and CS $(0.392,0.366,0.247$, and $0.217 \mathrm{mg} \mathrm{m}^{-2} \mathrm{~h}^{-1}$, respectively). The sampling at week 4 produced greater $(\mathrm{p}<0.0001) \mathrm{N}_{2} \mathrm{O}$ flux compared to weeks 5 and 6 , and $\mathrm{N}_{2} \mathrm{O}$ flux decreased as the packs aged ( 0.484 , 0.246 , and $0.186 \mathrm{mg} \mathrm{m}^{-2} \mathrm{~h}^{-1}$, respectively). Similarly, Parker et al. (2018) reported that $\mathrm{N}_{2} \mathrm{O}$ levels decreased over 18 days as a result of denitrification within feedlot manure. Bedded packs in the HOT treatments produced significantly ( $p<$ 0.0001 ) greater flux compared to the COOL treatments ( 0.449 vs. $0.162 \mathrm{mg} \mathrm{m}^{-2} \mathrm{~h}^{-1}$, respectively). Nitrous oxide flux is produced by both nitrification and denitrification processes, which are influenced by moisture and temperature (Parker et al., 2017). Similarly, Woodbury et al. (2018) reported that $\mathrm{N}_{2} \mathrm{O}$ flux from feedlot manure increased from 0.170 to $0.995 \mathrm{~g} \mathrm{~m}^{-2} \mathrm{~d}^{-1}$ as temperature increased from $5^{\circ} \mathrm{C}$ to $35^{\circ} \mathrm{C}$. The change in ambient temperature at week 3 , when the bedded packs were moved from $18^{\circ} \mathrm{C}$ to their respective treatment temperatures, may be the cause of the $\mathrm{N}_{2} \mathrm{O}$ peaks at week 4. However, in a previous 6-week lab-scale bedded pack study, Spiehs et al. (2019) observed a spike in $\mathrm{N}_{2} \mathrm{O}$ around week 3 followed by a decrease to week 6 .

\section{GLOBAL WARMing Potential}

Global warming potential (GWP) provides the ability to compare gases based on how much energy the emissions of one ton of gas will absorb over given period of time (EPA, 2019). The GWP of $\mathrm{N}_{2} \mathrm{O}$ is 298 times that of $\mathrm{CO}_{2}$ for a $100-$ year time scale (EPA, 2019). In the current study, the $\mathrm{N}_{2} \mathrm{O}$ flux from the bedding materials containing $\mathrm{BS}, \mathrm{CS}, \mathrm{PC}$, and WS resulted in $\mathrm{CO}_{2}$ equivalents of 73.6, 64.7, 109.1, and $116.8 \mathrm{mg} \mathrm{m}^{-2} \mathrm{~h}^{-1}$, respectively, based on the GWP of $\mathrm{N}_{2} \mathrm{O}$. Meanwhile, the GWP of $\mathrm{CH}_{4}$ is 25 times that of $\mathrm{CO}_{2}$ for a 100-year time scale (EPA, 2019). The $\mathrm{CH}_{4}$ flux from the bedding materials containing $\mathrm{BS}, \mathrm{CS}, \mathrm{PC}$, and WS resulted in $\mathrm{CO}_{2}$ equivalents of $81.9,95.5,22.0$, and $38.3 \mathrm{mg} \mathrm{m}^{-2} \mathrm{~h}^{-1}$,

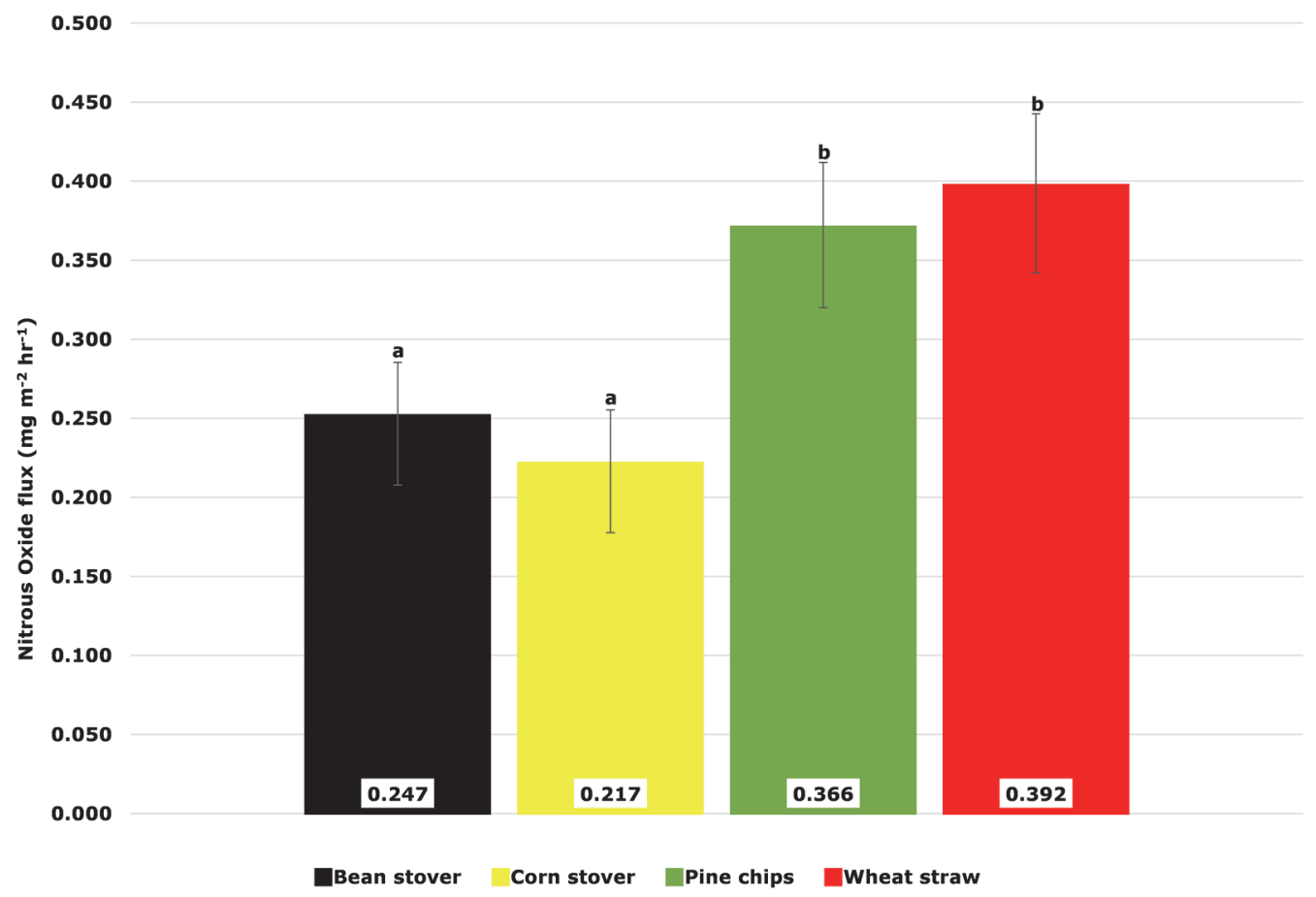

Figure 10. Average nitrous oxide flux $\left(\mathrm{mg} \mathrm{m}^{-2} \mathrm{~h}^{-1}\right)$ in headspace air above lab-scale bedded packs stored at $\operatorname{cool}\left(15^{\circ} \mathrm{C}\right)$ and hot $\left(30^{\circ} \mathrm{C}\right)$ temperatures and containing bean stover, corn stover, pine wood chips, or wheat straw. Values are least square means; error bars indicate standard errors. Least square means with different letters are significantly different $(p<0.05)$. For bedding material difference, $p<0.0001$. 
respectively, based on the GWP of $\mathrm{CH}_{4}$. Considering the total $\mathrm{CO}_{2}$ equivalents of $\mathrm{CH}_{4}$ and $\mathrm{N}_{2} \mathrm{O}$, the $\mathrm{CS}$ bedding material was the greatest at $160.2 \mathrm{mg} \mathrm{m}^{-2} \mathrm{~h}^{-1}$, while PC was the lowest at $131.0 \mathrm{mg} \mathrm{m}^{-2} \mathrm{~h}^{-1}$.

\section{CONCLUSIONS}

A significant $(\mathrm{p}<0.0001)$ three-way interaction for bedding material by temperature by age of the bedded pack was observed for $\mathrm{CH}_{4}$. Significantly greater $\mathrm{CH}_{4}$ flux was observed in the headspace above HOT-BS and HOT-CS (10.48 and $12.59 \mathrm{mg} \mathrm{m}^{-2} \mathrm{~h}^{-1}$, respectively) at week 6 compared to all other treatments. A significant bedding material by temperature interaction was observed for $\mathrm{NH}_{3}, \mathrm{H}_{2} \mathrm{~S}$, and $\mathrm{CO}_{2}$ ( $p=0.0094, p<0.0001$, and $p=0.0189$, respectively). Ammonia emissions were lower for the COOL treatments than for the HOT treatments throughout the study. Corn stover bedding produced the lowest $\mathrm{NH}_{3}$ flux over time at both COOL and HOT temperatures (122.2 and $242.7 \mathrm{mg} \mathrm{m}^{-2} \mathrm{~h}^{-1}$, respectively). In bedded pack operations where $\mathrm{NH}_{3}$ and respiratory issues are a concern, CS bedding material should be considered to minimize $\mathrm{NH}_{3}$ volatilization, with the downside of increasing GHG release. Hydrogen sulfide flux was lowest from the HOT treatments, while WS bedding material produced the lowest $\mathrm{H}_{2} \mathrm{~S}$ flux in both COOL and HOT treatments (20.7 and $5.6 \mathrm{mg} \mathrm{m}^{-2} \mathrm{~h}^{-1}$, respectively). Significantly $(\mathrm{p}<0.0001)$ greater $\mathrm{H}_{2} \mathrm{~S}$ was produced in the headspace of COOL-BS compared to all other treatments. Greenhouse gas emissions tended to be higher from bedded packs at HOT temperatures. The largest $\mathrm{CO}_{2}$ levels were observed above WS, regardless of temperature. Nitrous oxide flux decreased over time for all bedded packs, while WS and PC bedded packs produced the greatest $\mathrm{N}_{2} \mathrm{~S}$ flux $(0.392$ and $0.366 \mathrm{mg}$ $\mathrm{m}^{-2} \mathrm{~h}^{-1}$, respectively). Corn stover bedding material resulted is the greatest combined $\mathrm{CO}_{2}$ equivalents for $\mathrm{CH}_{4}$ and $\mathrm{N}_{2} \mathrm{O}$.

The results of this study indicate that feedlot operators maintaining bedded pack facilities will have the greatest reduction in $\mathrm{NH}_{3}$ emissions when using $\mathrm{CS}$ bedding, regardless of the ambient temperature. To reduce $\mathrm{CH}_{4}$ emissions, producers should avoid allowing BS and CS bedded packs to be maintained for longer than six weeks in HOT $\left(30^{\circ} \mathrm{C}\right)$ temperatures; frequent cleaning during summer months is recommended. Based on the combined $\mathrm{CO}_{2}$ equivalents of $\mathrm{CH}_{4}$ and $\mathrm{N}_{2} \mathrm{O}$, producers should consider $\mathrm{PC}$ as option to reduce GHG emissions.

\section{ACKNOWLEDGEMENTS}

The authors wish to acknowledge Alan Kruger, Cindy Felber, and Sue Wise for their assistance with the study construction, data collection, and processing. This project was funded by appropriated funds from the USDA. The USDA is an equal opportunity provider and employer. The mention of trade names of commercial products in this article is solely for the purpose of providing specific information and does not imply recommendation or endorsement by the USDA.

\section{REFERENCES}

Andriamanohiarisoamanana, F. J., Sakamoto, Y., Yamashiro, T., Yasui, S., Iwasaki, M., Ihara, I., ... Umetsu, K. (2015). Effects of handling parameters on hydrogen sulfide emission from stored dairy manure. J. Environ. Mgmt., 154, 110-116. https://doi.org/10.1016/j.jenvman.2015.02.003

Archibeque, S. L., Freetly, H. C., Cole, N. A., \& Ferrell, C. L. (2007). The influence of oscillating dietary protein concentrations on finishing cattle: II. Nutrient retention and ammonia emissions. J. Animal Sci., 85(6), 1496-1503. https://doi.org/10.2527/jas.2006-208

Arogo, J., Zhang, R. H., Riskowski, G. L., \& Day, D. L. (1999). Mass transfer coefficient for hydrogen sulfide emission from aqueous solutions and liquid swine manure. Trans. ASAE, 42(5), 1455-1462. https://doi.org/10.13031/2013.13309

Ayadi, F. Y., Cortus, E. L., Spiehs, M. J., Miller, D. N., \& Djira, G. D. (2015). Ammonia and greenhouse gas concentrations at surfaces of simulated beef cattle bedded manure packs. Trans. ASABE, 58(3), 783-795. https://doi.org/10.13031/trans.58.10961

Bierman, S., Erickson, G. E., Klopfenstein, T. J., Stock, R. A., \& Shain, D. H. (1999). Evaluation of nitrogen and organic matter balance in the feedlot as affected by level and source of dietary fiber. J. Animal Sci., 77(7), 1645-1653. https://doi.org/10.2527/1999.7771645x

Brown-Brandl, T. M., Nienaber, J. A., \& Eigenberg, R. A. (2011). Temperature and humidity control in indirect calorimeter chambers. Trans. ASABE, 54(2), 685-692. https://doi.org/10.13031/2013.36471

Bryant, M. P. (1979). Microbial methane production: Theoretical aspects. J. Animal Sci., 48(1), 193-201. https://doi.org/10.2527/jas1979.481193x

Chadwick, D., Sommer, S., Thorman, R., Fangueiro, D., Cardenas, L., Amon, B., \& Misselbrook, T. (2011). Manure management: Implications for greenhouse gas emissions. Animal Feed Sci. Tech., 166-167, 514-531. https://doi.org/10.1016/j.anifeedsci.2011.04.036

Cole, N. A., Clark, R. N., Todd, R. W., Richardson, C. R., Gueye, A., Greene, L. W., \& McBride, K. (2005). Influence of dietary crude protein concentration and source on potential ammonia emissions from beef cattle manure. J. Animal Sci., 83(3), 722731. https://doi.org/10.2527/2005.833722x

Cortus, E. L., Al Mamun, M. R., Ayadi, F. Y., Spiehs, M. J., Pohl, S., Doran, B. E., ... Nicolai, R. (2013). Manure management and temperature impacts on gas concentrations in mono-slope cattle facilities. Proc. Waste to Worth: Spreading Science and Solution. Retrieved from https://lpelc.org/manure-managementand-temperature-impacts-on-gas-concentrations-in-mono-slopecattle-facilities/

Cortus, E. L., Spiehs, M. J., Doran, B. E., Al Mamun, M. R., Ayadi, F. Y., Cortus, S. D., ... Nicolai, R. (2014). Ammonia and hydrogen sulfide concentration and emission patterns for monoslope beef cattle facilities in the Northern Great Plains. ASABE Paper No. 141897896. St. Joseph, MI: ASABE.

Doran, B., Euken, R., \& Spiehs, M. J. (2010). Hoops and monoslopes: What we have learned about management and performance. Proc. Feedlot Forum (pp. 8-16). Ames, IA: Iowa State University, Iowa Beef Center.

EPA. (2019). Inventory of U.S. greenhouse gas emissions and sinks: 1990-2017. Washington, DC: U.S. Environmental Protection Agency. Retrieved from www.epa.gov/sites/production/files/2019-04/documents/us-ghginventory-2019-main-text.pdf

Garlipp, F., Hessel, E. F., \& van den Weghe, H. F. A. (2011). Characteristics of gas generation $\left(\mathrm{NH}_{3}, \mathrm{CH}_{4}, \mathrm{~N}_{2} \mathrm{O}, \mathrm{CO}_{2}, \mathrm{H}_{2} \mathrm{O}\right)$ from horse manure added to different bedding materials used in 
deep litter bedding systems. J. Equine Vet. Sci., 31(7), 383-395. https://doi.org/10.1016/j.jevs.2011.01.007

Hao, X., Chang, C., Larney, F. J., \& Travis, G. R. (2001). Greenhouse gas emissions during cattle feedlot manure composting. J. Environ. Qual., 30(2), 376-386. https://doi.org/10.2134/jeq2001.302376x

Hooser, S. B., Van Alstine, W., Kiupel, M., \& Sojka, J. (2000). Acute pit gas (hydrogen sulfide) poisoning in confinement cattle. J. Vet. Diag. Invest., 12(3), 272-275. https://doi.org/10.1177/104063870001200315

Jarvis, S. C., Lovell, R. D., \& Panayides, R. (1995). Patterns of methane emission from excreta of grazing animals. Soil Biol. Biochem., 27(12), 1581-1588. https://doi.org/10.1016/00380717(95)00092-S

Johnson, K. A., \& Johnson, D. E. (1995). Methane emissions from cattle. J. Animal Sci., 73(8), 2483-2492. https://doi.org/10.2527/1995.7382483x

Kebreab, E., Johnson, K. A., Archibeque, S. L., Pape, D., \& Wirth, T. (2008). Model for estimating enteric methane emissions from United States dairy and feedlot cattle. J. Animal Sci., 86(10), 2738-2748. https://doi.org/10.2527/jas.2008-0960

Koelsch, R. K., Erickson, G. E., Homolka, M. N., \& Luebbe, M. (2018). Predicting manure nitrogen, phosphorus, and carbon characteristics of beef open-lot systems. ASABE Paper No. 1800946. St. Joseph, MI: ASABE. https://doi.org/10.13031/aim.201800946

Koenig, K. M., \& McGinn, S. M. (2016). Effect of temperature on ammonia emissions from feedlot cattle manure. J. Animal Sci., 94(supp. 5), 569-570. https://doi.org/10.2527/jam2016-1187

Li, W., Powers, W., \& Hill, G. M. (2011). Feeding distillers dried grains with solubles and organic trace mineral sources to swine and the resulting effect on gaseous emissions. J. Animal Sci., 89(10), 3286-3299. https://doi.org/10.2527/jas.2010-3611

Linderholm, A. L., Findleton, C. L., Kumar, G., Hong, Y., \& Bisson, L. F. (2008). Identification of genes affecting hydrogen sulfide formation in Saccharomyces cerevisiae. Appl. Environ. Microbiol., 74(5), 1418-1427. 10.1128/aem.01758-07

Ludwig, H. R., Cairelli, S. G., \& Whalen, J. J. (1994). Documentation for immediately dangerous to life or health concentrations (IDLHs). Washington, DC: NIOSH. Retrieved from https://www.cdc.gov/niosh/idlh/pdfs/1994-IDLHValuesBackgroundDocs.pdf

Mackie, R. I., Stroot, P. G., \& Varel, V. H. (1998). Biochemical identification and biological origin of key odor components in livestock waste. J. Animal Sci., 76(5), 1331-1342. https://doi.org/10.2527/1998.7651331x

Meisinger, J. J., \& Jokela, W. E. (2000). Ammonia volatilization from dairy and poultry manure. In Managing nutrients and pathogens from animal agriculture (pp. 334-354). NRAES-130. Ithaca, NY: Natural Resource, Agriculture, and Engineering Service.

Miller, D. N., \& Varel, V. H. (2001). In vitro study of the biochemical origin and production limits of odorous compounds in cattle feedlots. J. Animal Sci., 79(12), 2949-2956. https://doi.org/10.2527/2001.79122949x

Misselbrook, T. H., \& Powell, J. M. (2005). Influence of bedding material on ammonia emissions from cattle excreta. J. Dairy Sci., 88(12), 4304-4312. https://doi.org/10.3168/jds.S00220302(05)73116-7

Mitloehner, F. M., \& Calvo, M. S. (2008). Worker health and safety in concentrated animal feeding operations. J. Agric. Saf. Health, 14(2), 163-187. https://doi.org/10.13031/2013.24349

Moraes, L. E., Burgos, S. A., DePeters, E. J., Zhang, R. H., \& Fadel, J. G. (2017). Urea hydrolysis in dairy cattle manure under different temperature, urea, and $\mathrm{pH}$ conditions. J. Dairy Sci., 100(3), 2388-2394. https://doi.org/10.3168/jds.2016-11927
Ni, J. Q., Heber, A. J., Sutton, A. L., \& Kelly, D. T. (2009). Mechanisms of gas releases from swine wastes. Trans. ASABE, 52(6), 2013-2025. https://doi.org/10.13031/2013.29203

Parker, D. B., Caraway, E. A., Rhoades, M. B., Cole, N. A., Todd, R. W., \& Casey, K. D. (2010). Effect of wind tunnel air velocity on VOC flux from standard solutions and CAFO manure/wastewater. Trans. ASABE, 53(3), 831-845. https://doi.org/10.13031/2013.30066

Parker, D. B., Waldrip, H. M., Casey, K. D., Todd, R. W., Willis, W. M., \& Webb, K. (2017). Temporal nitrous oxide emissions from beef cattle feedlot manure after a simulated rainfall event. J. Environ. Qual., 46(4), 733-740. https://doi.org/10.2134/jeq2017.02.0042

Parker, D. B., Waldrip, H. M., Casey, K. D., Woodbury, B. L., Spiehs, M. J., Webb, K., \& Willis, W. M. (2018). How do temperature and rainfall affect nitrous oxide emissions from open-lot beef cattle feedyard pens? Trans. ASABE, 61(3), 10491061. https://doi.org/10.13031/trans. 12788

Sakar, S., Yetilmezsoy, K., \& Kocak, E. (2009). Anaerobic digestion technology in poultry and livestock waste treatment: A literature review. Waste Mgmt. Res., 27(1), 3-18. https://doi.org/10.1177/0734242X07079060

Spiehs, M. J. (2018). Lab-scale model to evaluate odor and gas concentrations emitted by deep bedded pack manure. $J$. Visualized Expt.,(137), e57332. https://doi.org/10.3791/57332

Spiehs, M. J., Berry, E. D., Wells, J. E., Parker, D. B., \& BrownBrandl, T. M. (2017). Odorous volatile organic compounds, Escherichia coli, and nutrient concentrations when kiln-dried pine chips and corn stover bedding are used in beef bedded manure packs. J. Environ. Qual., 46(4), 722-732. https://doi.org/10.2134/jeq2016.09.0333

Spiehs, M. J., Brown-Brandl, T. M., Berry, E. D., Wells, J. E., Parker, D. B., Miller, D. N., ... DiCostanzo, A. (2014a). Use of wood-based materials in beef bedded manure packs: 2 . Effect on odorous volatile organic compounds, odor activity value, Escherichia coli, and nutrient concentrations. J. Environ. Qual., 43(4), 1195-1206. https://doi.org/10.2134/jeq2013.05.0165

Spiehs, M. J., Brown-Brandl, T. M., Parker, D. B., \& Miller, D. N. (2012). Effect of bedding material on air quality of bedded manure packs in livestock facilities. ASABE Paper No. 121337890. St. Joseph, MI: ASABE.

Spiehs, M. J., Brown-Brandl, T. M., Parker, D. B., Miller, D. N., Berry, E. D., \& Wells, J. E. (2013). Effect of bedding materials on concentration of odorous compounds and Escherichia coli in beef cattle bedded manure packs. J. Environ. Qual., 42(1), 6575. https://doi.org/10.2134/jeq2012.0251

Spiehs, M. J., Brown-Brandl, T. M., Parker, D. B., Miller, D. N., Berry, E. D., \& Wells, J. E. (2016). Ammonia, total reduced sulfides, and greenhouse gases of pine chip and corn stover bedding packs. J. Environ. Qual., 45(2), 630-637. https://doi.org/10.2134/jeq2015.09.0466

Spiehs, M. J., Brown-Brandl, T. M., Parker, D. B., Miller, D. N., Jaderborg, J. P., DiCostanzo, A., ... Wells, J. E. (2014b). Use of wood-based materials in beef bedded manure packs: 1 . Effect on ammonia, total reduced sulfide, and greenhouse gas concentrations. J. Environ. Qual., 43(4), 1187-1194. https://doi.org/10.2134/jeq2013.05.0164

Spiehs, M. J., Woodbury, B. L., \& Parker, D. B. (2019). Ammonia, hydrogen sulfide, and greenhouse gas emissions from lab-scaled manure bedpacks with and without aluminum sulfate additions. Environ., 6(10), 108. https://doi.org/10.3390/environments6100108

Spiehs, M. J., Woodbury, B. L., Doran, B. E., Eigenberg, R. A., Kohl, K. D., Varel, V. H., ... Wells, J. E. (2011). Environmental conditions in beef deep-bedded mono-slope facilities: A 
descriptive study. Trans. ASABE, 54(2), 663-673.

https://doi.org/10.13031/2013.36469

Varel, V. H. (1997). Use of urease inhibitors to control nitrogen loss from livestock waste. Bioresour. Tech., 62(1), 11-17. https://doi.org/10.1016/S0960-8524(97)00130-2

Woodbury, B. L., Gilley, J. E., Parker, D. B., \& Stromer, B. S. (2018). Greenhouse gas emissions from beef feedlot surface materials as affected by diet, moisture, temperature, and time. Trans. ASABE, 61(2), 571-582.

https://doi.org/10.13031/trans.12483
Yongsiri, C., Vollertsen, J., \& Hvitved-Jacobsen, T. (2004). Effect of temperature on air-water transfer of hydrogen sulfide. $J$. Environ. Eng., 130(1), 104-109. https://doi.org/10.1061/(ASCE)0733-9372(2004)130:1(104)

Zang, B., Li, S., Michel, F. C., Li, G., Zhang, D., \& Li, Y. (2017). Control of dimethyl sulfide and dimethyl disulfide odors during pig manure composting using nitrogen amendment. Bioresour. Tech., 224, 419-427.

https://doi.org/10.1016/j.biortech.2016.11.023 